\title{
Infertility in Men in Relation to Their Birth Characteristics
}

\section{Susanne Liffner}

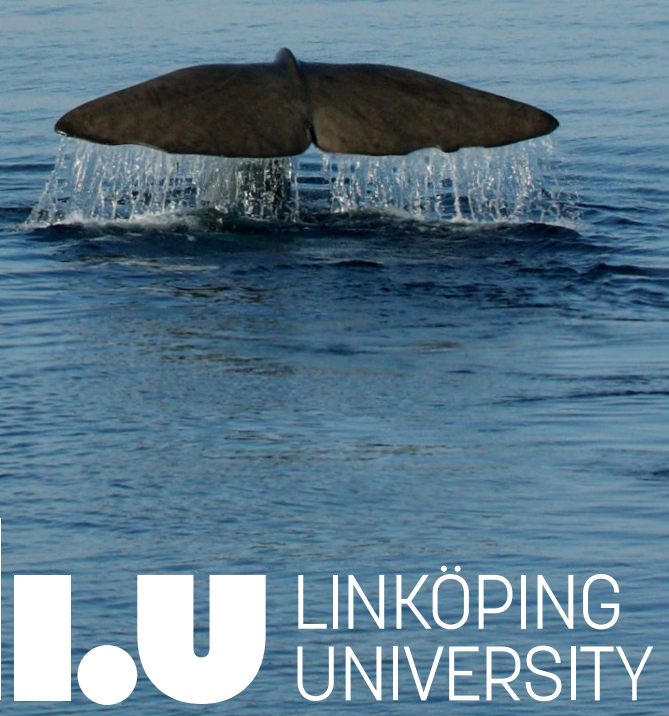





\title{
Infertility in Men in Relation to Their Birth Characteristics
}

\author{
Susanne Liffner
}

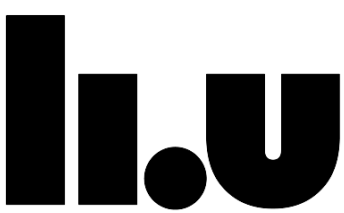

LINKÖPING UNIVERSITY

Department of Biomedical and Clinical Sciences

Linköping University, Sweden

Linköping 2021 
Infertility in Men in Relation to Their Birth Characteristics

(c) EY-NC This work is licensed under a Creative Commons AttributionNonCommercial 4.0 International License.

https://creativecommons.org/licenses/by-nc/4.0/

(c) Susanne Liffner, 2021

Cover: Published by permission of iStock.com/anzeletti

Published articles has been reprinted with the permission of the copyright holder.

Printed in Sweden by LiU-Tryck, Linköping, Sweden, 2021

ISBN: 978-91-7929-049-8 (print)

ISBN: 978-91-7929-050-4 (PDF)

ISSN: 0345-0082 


\section{Abstract}

Background: About 10-15 \% of couples worldwide suffer from infertility, the inability to achieve a pregnancy after more than 12 months of unprotected intercourse. Causes can be related to female factors, male factors, or both. In about $20 \%$ of the couples, the cause remains unexplained. Male factor infertility is based on semen sample evaluation and is defined as poor semen quantity or quality, preferably in two or more samples. When assisted reproductive technology (ART) is considered for a couple with male factor infertility, intracytoplasmic sperm injection (ICSI) where the sperm is injected into the oocyte, is often needed to achieve embryo development.

Men born small for gestational age (SGA), with low birth weight (LBW, $\leq 2,5000$ ) and/or prematurely (before the $37^{\text {th }}$ gestational week) do not become fathers as often as men born with appropriate size for gestational age (AGA) at term. The aims of the present thesis were to investigate if this lower likelihood to become a father for men born SGA, preterm, or with low birth weight could be related to an increased risk of male factor infertility, if ICSI and sperm donation more often were needed and if the chance of conceiving by ART was lower than in men born AGA. An additional aim was to investigate if sperm DNA damage was more common in men born SGA compared with men born with normal size for gestational age.

Material and Methods: Paper I and II were based on retrospective case control studies on men becoming fathers by ART in study I, and infertile men, patients at the Centre of Reproductive Medicine, University Hospital, Linköping, Sweden (RMC), in study II. Paper III was based on a cohort study on all men born in Sweden between 1973 and 1993. All three studies used data from national registers held by the National Board of Health and Welfare and Statistics Sweden. Study III also used information from the Swedish National Quality Register of Assisted Reproduction.

Paper IV was based on a case series study of sperm DNA fragmentation in infertile patients and sperm donors at RMC, where two different methods of measuring sperm DNA fragmentation were compared, Halosperm ${ }^{\circledR}$ (easier to perform) and Sperm Chromatin Structure Assay (reference method). Paper V was based on a cohort study of men undergoing ART at RMC. The proportion of sperm with DNA fragmentation was compared between men born SGA and men born AGA.

Results and conclusions: Men becoming fathers after ART were more often born with low birth weight than men conceiving naturally. Men becoming 
fathers after ICSI, presuming a poor semen sample, were more often born SGA than men conceiving by conventional IVF, or conceiving without treatment. ICSI had to be performed in $63 \%$ of men born SGA but only in $45 \%$ of men born AGA. Men with male factor infertility were more often born SGA or with LBW than men with female factor infertility, or when the infertility was unexplained. The results after ART were not affected by birth weight or size at birth.

The likelihood of becoming a father was lower for men born SGA or with LBW compared with men born with normal birth weight. These men were also more often single (never married or with a registered partner) and had a higher risk of being born with undescended testicles, which increases the risk of infertility. Men born SGA more often needed ICSI or sperm donation.

The two different methods to analyse sperm DNA fragmentation had high correlation and agreement, and Halosperm ${ }^{\circledR}$ could be considered a reliable and more easily handled method in the clinical setting. The median proportion of sperm with DNA fragmentation were higher for men born SGA (16.6\%) compared with men born AGA (6.4\%). The result was not statistically significant as the absolute number of men born SGA was much smaller than expected in this sample of 550 men. Larger studies are needed to confirm the hypothesis that DNA fragmentation contributes to a lower likelihood to become a father in men born SGA. 


\section{List of scientific papers}

I. Men becoming fathers by intracytoplasmic sperm injection were more often born small for gestational age

Susanne Liffner, Mats Hammar, Marie Bladh, Elizabeth Nedstrand, Heriberto Rodriguez Martinez, Gunilla Sydsjö Asian J Androl. 2017 Jan-Feb;19(1):103-106

II. Birth Characteristics in men with infertility

Susanne Liffner, Elizabeth Nedstrand, Marie Bladh, Heriberto Rodriguez Martinez, Gunilla Sydsjö

Reprod Biomed Online. 2020 Sep;41(3):455-463.

III. Men born small for gestational age or with low birth weight do not improve their rate of reproduction over time: a Swedish population-based study

Susanne Liffner, Marie Bladh, Elizabeth Nedstrand, Mats Hammar, Heriberto Rodriguez Martinez, Gunilla Sydsjö

Fertil Steril. 2021 Sep;116(3):721-730

IV. Diagnostics of DNA fragmentation in human spermatozoa: Are sperm chromatin structure analysis and sperm chromatin dispersion tests (SCD-HalospermG2 ${ }^{\circledR}$ ) comparable?

Susanne Liffner, Isabelle Pehrson, Laura Garcia-Calvo, Elizabeth Nedstrand, Stefan Zalavary, Mats Hammar, Heriberto Rodriguez Martinez, Manuel Alvarez Rodriguez

Andrologia. 2019 Sep;51(8):e13316

V. DNA fragmentation in spermatozoa after density centrifugation in relation to infertility factor and size for gestational age

Susanne Liffner, Marie Bladh, Mats Hammar, Elizabeth Nedstrand, Heriberto Rodriguez Martinez, Gunilla Sydsjö, Manuel Alvarez Rodriguez Manuscript 



\section{Abbreviations}

AGA

$\mathrm{AMH}$

ART

BA

BMI

CI

CV

DFI

FSH

GnRH

hCG

HDS

hMG

ICSI

IUGR

IUI

IVF

LBW

LGA

LH

MBR

NPR

PTB

RMC

SCD

SCSA

SD

SDF

SGA

TPR

TUNEL

WHO
Appropriate for Gestational Age (a birth weight $>-2 \mathrm{SD}$ and $<+2$ SD of the mean weight for the gestational age) Anti-Müllerian Hormone

Assisted Reproductive Technology

Bland Altman Plot

Body Mass Index $\left(\mathrm{kg} / \mathrm{m}^{2}\right)$

Confidence Interval

Coefficient of Variation

DNA Fragmentation Index

Follicle Stimulating Hormone

Gonadotropin Releasing Hormone

Human Chorionic Gonadotropin

High DNA Staining/Stainability

Human Menopausal Gonadotropin

Intra-Cytoplasmic Sperm Injection

Intra-Uterine Growth Retardation

Intra-Uterine Insemination

In Vitro Fertilisation

Low Birth Weight (a birth weight $<2,500 \mathrm{~g}$ )

Large for Gestational Age (a birth weight $>+2 \mathrm{SD}$ of the mean weight for the gestational age)

Luteinizing Hormone

Medical Birth Register

National Patient Register

Pre-Term Birth

Centre of Reproductive Medicine, Linköping University Hospital

Sperm Chromatin Dispersion

Sperm Chromatin Structure Assay

Standard Deviation

Sperm DNA Fragmentation

Small for Gestational Age (a birth weight $<-2$ SD of the mean weight for the gestational age)

Total Population Register

Terminal deoxynucleotidyl transferase dUTP

(deoxyuridine triphosphate-biotin) Nick End Labeling World Health Organization 



\section{Content}

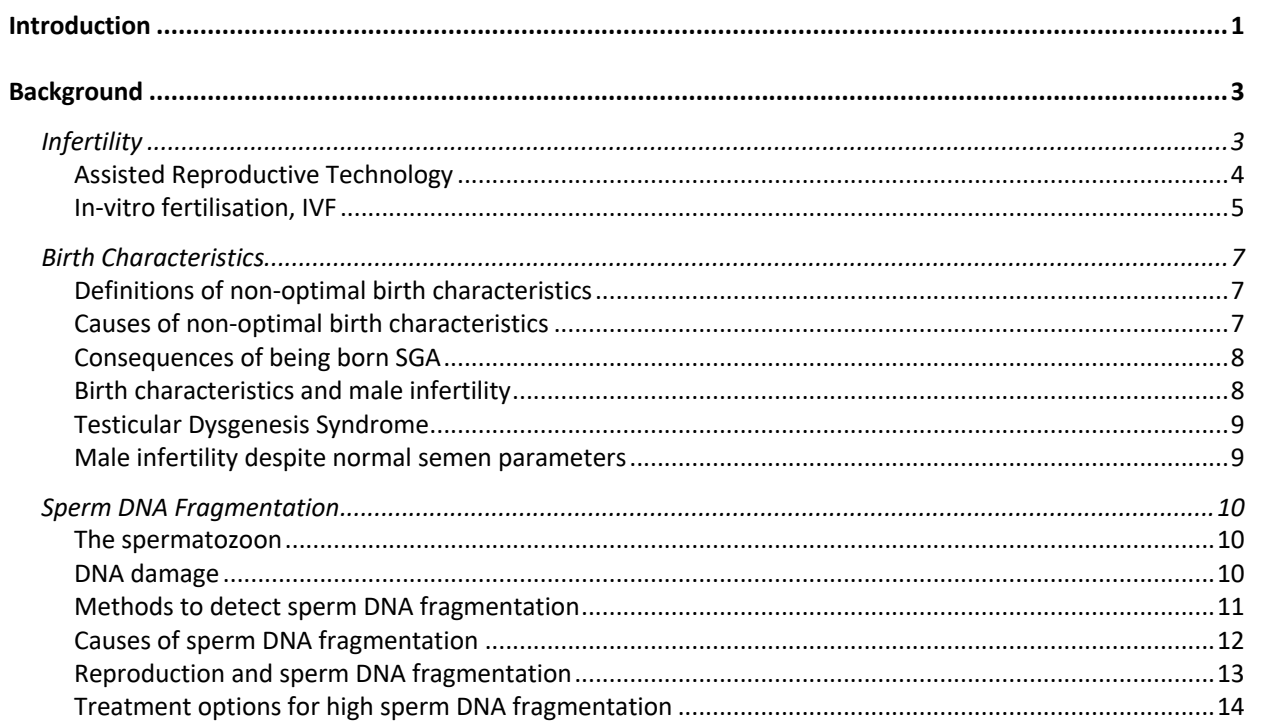

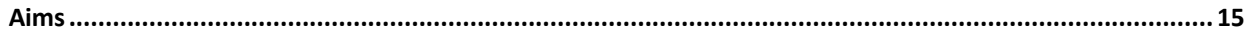

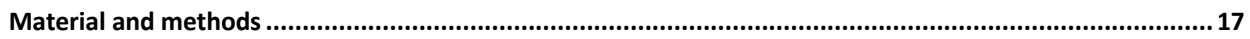

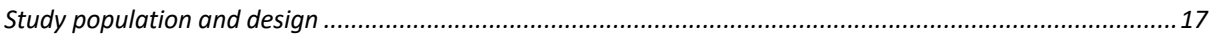

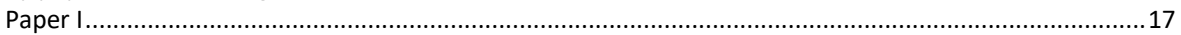

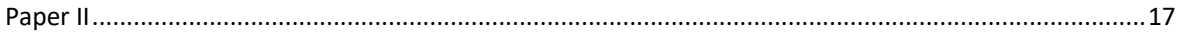



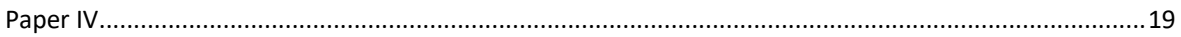

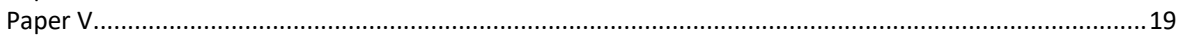

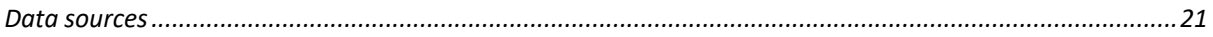

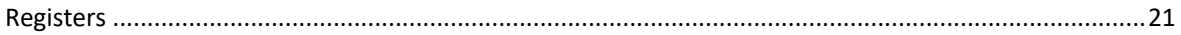

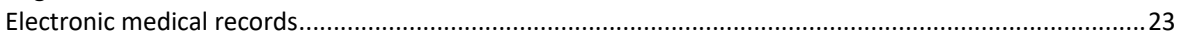

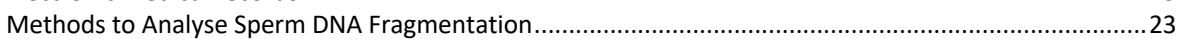

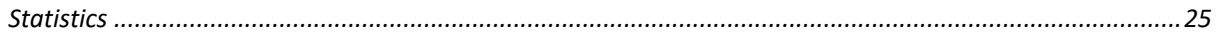

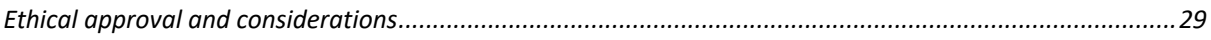

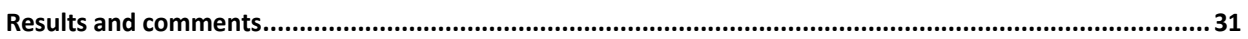

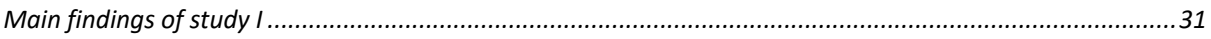

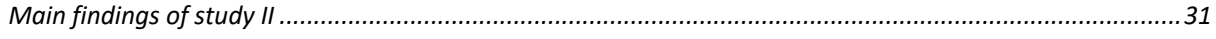

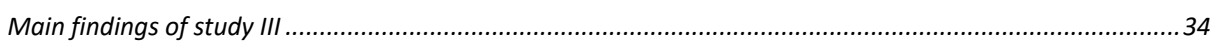

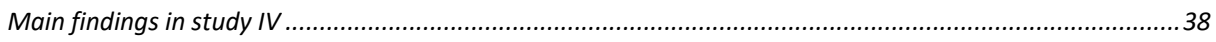

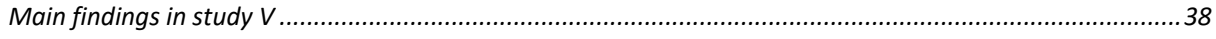



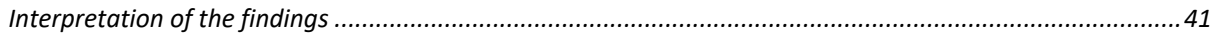


Methodological considerations

Methodological difficulties along the path as PhD student.

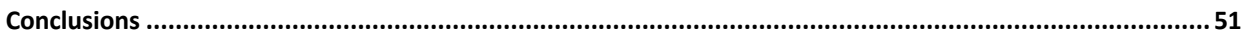

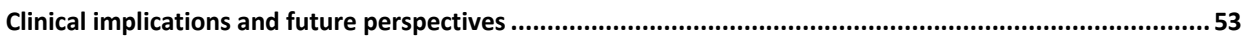

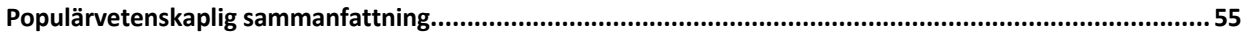

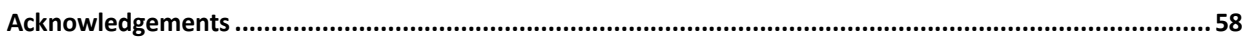

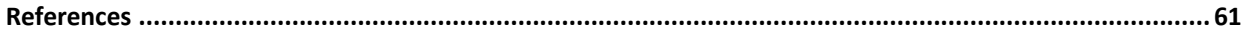




\section{Introduction}

Even if the man and the woman in an infertile couple are equally affected by their unfulfilled longing to become a parent, much of the focus during the clinical evaluation and treatment is on the female factors. But conception depends not only on the quality of the oocytes and the uterus. A sperm with the ability to deliver undamaged DNA to the oocyte is necessary for a successful fertilisation, implantation, and future development into a healthy child. Maybe other factors than the number and motility of sperm also matter. Events during the fetal period change the development of the testes and could in this way also influence the spermatogenesis and spermiogenesis in adult life.

The purpose of this thesis was to describe and evaluate the relationship between infertility in men and their birth characteristics. When studying the impact birth characteristics have on reproduction, infertility is not the only explanation to why the reproductive rates differ between men with different birth characteristics. The reproductive rate will be lower for men who have not become fathers, but this does not necessarily imply that they are infertile. They may not wish to become fathers, or maybe they have not found a partner. To address this problem, we have studied both the probability to become a father and, when performed, the type and results of assisted reproduction. Men born with birth characteristics suggesting a non-optimal fetal development (such as low birth weight and small size for gestational age) have been compared with men born without such signs. 


\section{Background}

\section{Infertility}

The inability to achieve a clinical pregnancy despite one year of regular, unprotected intercourse, is the WHO definition of infertility (1). The prevalence of infertility is estimated to impact between $10-25 \%$ of couples of reproductive age worldwide (estimates range from 48 to 180 million) (WHO 2020, (2).

Infertility is a complex disease where the evaluation of the couple unable to conceive may reveal causes related to either one or both partners as well as remaining unexplained. The age of the woman is a strong predictor of the chance to conceive even when including treatment options such as IVF but is maybe not to be considered an infertility factor. Female infertility factors are related to the ovaries and the ability to ovulate and includes a diminished ovarian reserve, to the function of the Fallopian tubes, where infections and endometriosis are the most common causes of total or partial tubal occlusion, or to the uterus and its ability to carry a pregnancy until the fetus is viable outside the womb (3).

Male infertility is primarily caused by low testicular production of normal spermatozoa (low sperm numbers, abnormal morphology), impaired sperm maturation (motility) or sperm dysfunction (inability to form a normal zygote), and is to some extent displayed by abnormal semen parameters (3). In the $5^{\text {th }}$ edition of the WHO laboratory manual for the examination of human semen, the lower reference values of normal semen parameters were defined as the $5^{\text {th }}$ percentile values for sperm concentration and total amount, motility, and morphology of fertile men, i.e., men that established a clinical pregnancy during the first 12 months of trying to conceive (4). The reference values have recently been revised and are now based on data from more than 3,500 men, see Table 1 $(5,6)$. A systemic review and meta-analysis in 2017 could report significant decline in sperm counts (total sperm count and sperm concentration) between 1973 and 2011, suggesting that male factor infertility may become even more common in the future if the decline continues (7).

A combined infertility factor refers to when both female and male factors are present. For the couples where evaluation of the infertility does not reveal any plausible causes, the infertility factor is labelled "unexplained". 
Table 1. Distribution of semen parameters for the fertile man and the 95\% CI for the $5^{\text {th }}$ percentile; WHO 2021

\begin{tabular}{lll}
\hline & $5^{\text {th percentile }}$ & $(95 \% \mathrm{CI})$ \\
Semen volume $(\mathrm{ml})$ & 1.4 & $\left(1.3^{-1.5}\right)$ \\
$\begin{array}{l}\text { Sperm concentration }\left(10^{6} \text { per } \mathrm{ml}\right) \\
\begin{array}{l}\text { Total sperm number }\left(10^{6} \text { per }\right. \\
\text { ejaculate) }\end{array}\end{array}$ & 16 & $(15-18)$ \\
Total motility (PR+NP, \%) & 42 & $(35-40)$ \\
Progressive motility (PR, \%) & 30 & $(40-43)$ \\
Non-progressive motility (NP, \%) & 1 & $(29-31)$ \\
Normal forms (morphology, \%) & 4 & $(1-1)$ \\
Immotile spermatozoa (IM, \%) & 20 & $(3.9-4.0)$ \\
Vitality (\%) & 54 & $(19-20)$
\end{tabular}

Semen parameters from WHO laboratory manual for the examination and processing of human semen, $6^{\text {th }}$ edition $(5,6)$.

\section{Assisted Reproductive Technology}

When a couple fails in achieving a pregnancy, some kind of assisted reproductive technology (ART) is often considered a treatment option. ART comprises all interventions that include the in vitro handling of both human oocytes and sperm or of embryos for the purpose of reproduction (3). This includes in-vitro fertilisation (IVF), intracytoplasmic sperm injection (ICSI), embryo transfers (ET) of fresh or frozen-thawed embryos as well as sperm and oocyte donation. The use of ART is increasing. In Sweden, more than 5,300 children conceived after ART were born in 2019 (8) which represents almost $5 \%$ of all childbirths. 


\section{In-vitro fertilisation, IVF}

IVF is a procedure including controlled ovarian stimulation, oocyte retrieval, sperm preparation, fertilisation, embryo culture and embryo transfer.

Controlled ovarian stimulation with Follicle Stimulating Hormone (FSH) or human Menopausal Gonadotropin (hMG), with effects similar of FSH, increases the number of growing follicles in the ovaries. Gonadotropin Releasing Hormone-antagonist (GnRH-antagonist) or $\mathrm{GnRH}$-agonist protocols to prevent premature ovulation are pursued. The spontaneous surge of Luteinizing Hormone (LH) must be suppressed by either a GnRH-antagonist usually started on day 5 of stimulation, or a GnRH-agonist administered before and during the stimulation with FSH. When the largest ovarian follicles have reached a size of about $20 \mathrm{~mm}$, the final oocyte maturation is triggered by either human Chorionic Gonadotropin (hCG) or a GnRH-agonist (9). The follicles are then emptied, and the oocytes retrieved, through ultrasound-guided transvaginal aspiration 36-38 h later.

A semen sample is provided by the male partner at the day of oocyte retrieval. If a fresh sample cannot be produced, thawing of previously frozen ejaculated or non-ejaculated (retrieved directly from the epididymis or testis) sperm or spermatids are other options. After analyses of semen parameters according to the WHO manual (6), sperm preparation is performed in order to eliminate seminal plasma and debris, to concentrate progressively motile sperm, and to select against morphologically abnormal sperm (10). Density gradient centrifugation is together with the swim-up technique the most frequently used preparation methods (10). Sperm preparation using density gradient centrifugation separates cells by their density alone, using density gradients consisting of colloidal silica coated with silane and usually results in a fraction of highly motile spermatozoa. The direct swim-up technique is performed by layering culture medium over the liquefied semen, and motile spermatozoa can thereafter swim into the culture medium (6). 
Retrieved oocytes can be inseminated by conventional IVF or by ICSI (shown in figure 1). Conventional IVF is used when the sperm preparation led to a sufficient concentration of progressively motile sperm (typically a concentration between $0.4-1.0 \times 10^{6} / \mathrm{mL}$ is used as a cut-off) (10). When the concentration of progressively motile sperm is lower, the cumulus cells are removed from the oocytes (denudation) and one single spermatozoon is injected into each mature oocyte. The first childbirths after ICSI were described in 1992 (11). The technique has been successful when treating men with low sperm quality, but also when using non-ejaculated sperm, collected from the epididymis or testis of azoospermic patients or when fertilising previously cryopreserved oocytes (12).

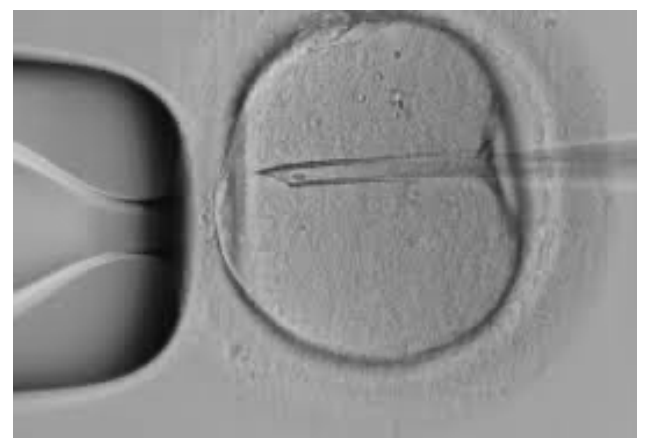

Figure 1. A sperm cell is injected into the oocyte

A successful and normal fertilisation is verified by the presence of two pronuclei in the oocyte at 16-18 $\mathrm{h}$ after insemination (or injection). The embryos are cultivated at $37^{\circ} \mathrm{C}$ in an incubator preferably with low oxygen levels until cleavage stage (day $2-3$ after oocyte retrieval) or blastocyst stage (day 5-6 after oocyte retrieval). The selection of what embryo to transfer is primarily based on developmental stage and morphological aspects (10). In almost all IVF cycles in Sweden, only one embryo is transferred into the uterus (8). Embryos of good quality can be cryopreserved and thawed and transferred in a later menstrual cycle. Most embryos are cryopreserved by vitrification at blastocyst stage. 


\section{Birth Characteristics}

The birth characteristics of interest in this thesis are the size for gestational age at birth, the weight at birth, and the gestational age at birth. The reason is that non-optimal birth characteristics such as being born prematurely, with low birth weight (LBW), and/or with a birth weight lower - and to a lesser extent, higher - than expected for gestational age at birth, can be associated with an increased risk of certain diseases and disabilities in adult life. The hypothesis of developmental origin of health and diseases has evolved from the initial studies of David Barker and colleagues, who described a relationship between low birth weight and ischemic heart disease as well as the metabolic syndrome (13-15). It was suggested that a suboptimal intrauterine environment resulted in embryonic and fetal responses which may cause adverse outcomes later in life (16).

\section{Definitions of non-optimal birth characteristics}

Whereas the WHO definition of LBW as a birth weight of less than 2,500g is accepted worldwide, the definition of SGA differs. The term is used to describe newborn infants whose weight and/or height is less than expected for their gestational age and sex. The WHO definition of SGA as the lowest $10^{\text {th }}$ percentile of the distribution of birth-weight-for-gestational age with the use of curves developed by Williams et al. has been considered too generous in classifying newborns as SGA $(17,18)$. Instead, SGA can be defined as a birth weight <-2SD of the mean birth weight for the infant's gestational age and this is together with the intrauterine growth curves based on ultrasonographic estimated fetal weights of children born in Sweden the definition used in this thesis (19-21). Preterm birth is defined as being born before the $37^{\text {th }}$ week of gestation.

\section{Causes of non-optimal birth characteristics}

The causes of being born with LBW, preterm birth (PTB) or small for gestational age (SGA) are multifactorial. Infections, short cervical length, and multiple gestation together with maternal characteristics and reproductive history such as smoking, body mass index (BMI) and previous PTB increase the risk of spontaneous PTB (22). Several of the risk factors for PTB are similar for LBW and SGA $(23,24)$. Placental abnormalities and genetic disorders of the fetus as 
well as environmental pollutants increase the risk of LBW and SGA and might also lead to iatrogenic PTB.

Low birth weight can be caused by a premature birth, when the weight is low since the gestational age is low, and is different from the concept of size for gestational age. Being born small for gestational age is often used as a token of intra-uterine growth restriction (IUGR) but it is not an equivalent. A difference must be made between a child born SGA who still has achieved its genetic growth potential and a child born SGA whose intrauterine growth has been restrained. The opposite also exists, when a child is born appropriate for gestational age (AGA) but still has not achieved its growth potential. These children are difficult to identify, especially in register studies where they will be classified as AGA and thereby belonging to the reference group.

\section{Consequences of being born SGA}

Children born SGA have an increased risk of both morbidity in the perinatal period, such as respiratory complications, hypothermia, and hypoglycaemia, and of long-term consequences $(24,25)$. Most children born SGA attain a normal height (i.e., above -2SD) through a phase of catch-up growth, usually finished within the first two years of life (24). About $10 \%$ of children born SGA, however, do not reach a normal adult height.

The weight gain during early childhood affects the body composition and especially SGA children with a spontaneous catch-up growth seem to have an increased risk of metabolic alterations in adulthood such as lower proportion of lean body mass, obesity, insulin resistance, and hypertension (16, 24). SGA-born individuals also have an increased risk of subnormal intellectual and psychological performance at young adulthood, particularly individuals without sufficient catch-up growth $(24,26,27)$.

\section{Birth characteristics and male infertility}

Male infertility was associated with LBW already in 1997 (28). In a later community-based cohort study of young adults investigating long-term consequences of being born SGA, time to pregnancy was not longer for men born SGA but they tried to conceive less often than men born AGA (29).

Men born SGA become fathers to a lesser extent and are more often diagnosed with infertility than men born AGA $(30,31)$. The causes are not fully understood but are probably multifactorial. Hormonal disturbances in men born LBW and 
SGA may contribute to reproductive difficulties but not all studies support these findings (32-36). Data on non-optimal birth characteristics and semen parameters are conflicting, where associations between birth weight and sperm count, concentration, and motility are found in some studies but not in all (3742).

\section{Testicular Dysgenesis Syndrome}

Impaired spermatogenesis together with cryptorchidism, hypospadias, and testicular cancer, are entities of the testicular dysgenesis syndrome (TDS) and the syndrome is more common in men born SGA $(43,44)$. Exposure to environmental agents such as endocrine disruptive chemicals or smoking but also genetic mutations might explain the increase in TDS in the population (4547).

\section{Male infertility despite normal semen parameters}

As previously discussed, male factor infertility is a diagnosis based solely on the analysis of semen parameters. Still, a normal spermiogram does not guarantee a fertilising potential. Other factors contributing to male fertility and reproduction have therefore been explored. DNA damage in spermatozoa has emerged as one of these factors, even if routine assessment of sperm DNA fragmentation (SDF) in clinical practice is not recommended (48). The lower likelihood of becoming a father for men born with non-optimal birth characteristics might, at least partly, be explained by a higher proportion of spermatozoa with DNA fragmentation but the subject is so far unexplored. 


\title{
Sperm DNA Fragmentation
}

\author{
The spermatozoon
}

The spermatozoon is a highly specialized cell, and its specific mission is to transfer genetic information into the haploid oocyte. The chromatin structure in spermatozoa is different from somatic cells. The packaging of DNA in spermatozoa is tighter and more condensed, rendering the sperm nucleus much smaller than a somatic cell nucleus and the DNA less vulnerable to, for instance, ionizing radiation. With the DNA tighter packaged, its intactness can be warranted until delivered to the oocyte. After fusion of the oocyte and sperm cell membranes, the sperm nucleus must rapidly release the sperm DNA. The ability of the sperm chromatin to condense and then rapidly decondense is crucial to sperm function. A sperm chromatin structure that has been compromised, damaged or even superstabilised may lead to false results when analysing sperm DNA (49).

\section{DNA damage}

Chromatin damage, i.e., defects in the DNA structure, include single or double DNA strand breaks, base deletion or modification, and inter- or intra-strand DNA cross-linkage $(50,51)$.

Any of these defects can induce sperm DNA fragmentation (SDF) but SDF particularly relates to single- or double-strand DNA breaks (51). The singlestrand breaks are considered less harmful as the other strand can still act as a template for replication. Both single- and double-strand breaks affect the fertility but while double-strand breaks interfere with embryo development, implantation rates, and have been associated with recurrent miscarriages, single-strand breaks have not been shown to impact implantation rates. High levels of single-strand breaks are inversely related to the natural pregnancy outcome and may also be inversely related to progressive sperm motility (52). Most available methods to assess SDF cannot differ between single- and doublestrand breaks. 




Figure 2. Sperm DNA fragmentation. Single and double strand breaks (50).

\section{Methods to detect sperm DNA fragmentation}

Methods to detect SDF use either enzymatic reactions to label the DNA breaks (Terminal deoxynucleotidyl transferase dUTP Nick End Labelling, TUNEL) or controlled DNA denaturation combined with protein depletion to detect DNA breaks (alkaline Comet assay, Sperm Chromatin Structure Assay (SCSA), and Sperm Chromatin Dispersion (SCD) (51).

The methods all measure DNA fragmentation and are useful to distinguish fertile and infertile men, but they measure different aspects of sperm chromatin structure $(53,54)$. The TUNEL assay detects the free $3^{\prime}-\mathrm{OH}$ ends of fragmented DNA and measures single-strand breaks and extensive double-strand breaks (52). The alkaline Comet assay measures mostly single-strand breaks and probably extensive double-strand breaks, thus assessing DNA fragmentation based on electrophoretic characteristics (52).

In this thesis, focus lies on SCD (Halosperm ${ }^{\circledR}$ G2) and SCSA. Both methods measure single-strand breaks and extensive double-strand breaks (52). SCSA is the oldest and therefore most used test to evaluate SDF. The DNA at the sites of single- and double-strand breaks is denaturated by acid exposure. Following later exposure to the metachromatic dye acridine orange and blue laser light, the intact double-stranded DNA emits green fluorescence while the damaged single-stranded DNA emits red fluorescence. The fluorescence is measured by flow cytometry and the ratio of red to red + green fluorescence is used to calculate the percentage of sperm with DNA fragmentation, DFI (DNA Fragmentation Index) (55). In addition to DFI, the SCSA also measures the percentage of sperm with high DNA stainability (HDS). HDS has been hypothesized to be a measurement of immaturity of the sperm nucleus. A high 
level of HDS has been suggested to reflect a deteriorated sperm nucleus compaction caused by a sub-optimal histone to protamine ratio and rendering the spermatozoa more susceptible to DNA damage $(56,57)$. However, even if HDS has been associated with protamine assessment, it has also been shown to correlate only poorly with tests that focus on the level of maturity of the sperm nucleus $(58,59)$.

When using the SCD method in glass slides, spermatozoa loaded with nonfragmented DNA produce a halo of dispersed DNA loops following acid denaturation and removal of nuclear proteins, as demonstrated in the SCD method. Spermatozoa embedded in agarose gel are treated with an acid denaturation solution to expose the sites of existing single- or doubled-stranded breaks. After removal of proteins, slides are stained and examined using brightfield or fluorescence microscopy to identify the DNA dispersion halos present in spermatozoa with non-fragmented DNA. The spermatozoa with DNA fragmentation form small or no halo at all (60), see figure 3.

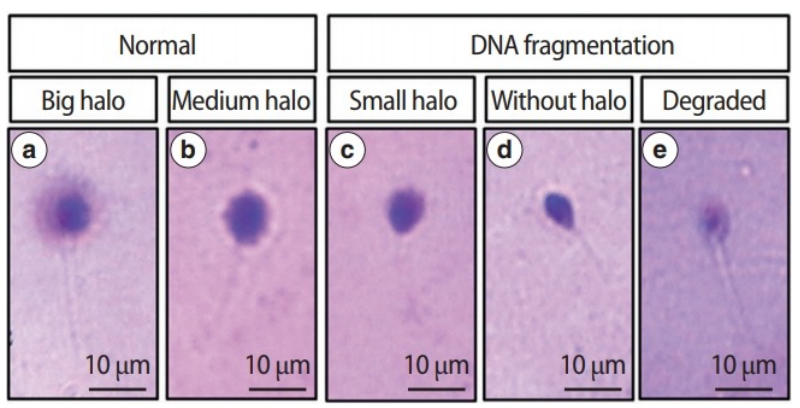

Figure 3. Spermatozoa with different type of halos.

From Le MT, Nguyen TTT, Nguyen TT, et al. Does conventional freezing affect sperm DNA fragmentation? Clin Exp Reprod Med. 2019;46(2):67-75

\section{Causes of sperm DNA fragmentation}

The SDF can be caused by and is associated with many conditions such as chronic illness, advanced age, obesity, environmental pollutants, heat exposure and smoking (51). During spermatogenesis, when the chromatin is compacted through histone exchange with protamines, unrepaired DNA breaks can lead to impairment of the packaging with a defective maturation as result. Chromatin condensation abnormalities have been related to decreased fertilization, decreased embryo quality, and impaired pregnancy rates (61). The SDF has also 
been suggested to be induced by abortive apoptosis, where defective germ cells escape the normal apoptosis process $(48,62)$. Oxidative stress contributes to male infertility partly through an increase in SDF. It represents an important explanation to why extrinsic factors such as ionizing radiation, smoking and heat exposure deteriorate the fertility potential of spermatozoa (63-66).

Several risk factors for male infertility, including age, varicocele, obesity, and testicular cancer, are also associated with increased SDF (50). High levels of SDF are inversely related to sperm count, motility, and normal morphology but the proportion of spermatozoa with SDF can be large even in ejaculates with otherwise normal semen parameters. Men with unexplained infertility more often have a high ( $\geq 20 \%$ ) DFI than men with proven fertility (26\% compared vs. 10\%) (67). Regardless of infertility factor, a systemic review and metaanalysis in 2018 reported that a SDF threshold level of $20 \%$ discriminated well between infertile and fertile men (68).

\section{Reproduction and sperm DNA fragmentation}

The impact of SDF on reproduction will depend on the severity of the DNA damage but also on the repair capacity of the oocyte (69). A mature oocyte with functional DNA repair mechanisms has the ability to repair moderate sperm DNA damage and it has been demonstrated that the age of the female seems to matter $(69,70)$. Normal embryo development could occur despite high levels of SDF when oocytes from younger females were used and fertilisation occurred to a similar extent in oocytes from older females, but subsequent embryo development was compromised (71). This implies that spermatozoa with SDF may retain their ability to fertilise the oocyte but if the DNA damage cannot be repaired by the oocyte, a lower chance of blastocyst formation and implantation will be the result (72).

A high degree of SDF diminishes the chance of natural conception and it is associated with decreased pregnancy rates after intra-uterine insemination (IUI), IVF and to a lesser extent after ICSI (73-77). High levels of SDF are also associated with an increased risk of miscarriage following both IVF and ICSI (50). Men in couples experiencing pregnancy loss after natural conception are also more likely to have a high SDF (78-81). 


\section{Treatment options for high sperm DNA fragmentation}

Treatment options are dependent on the suspected cause of high SDF. For men where oxidative stress seem to have induced SDF, antioxidant supplementation is sometimes recommended and can be purchased without prescription (50). The benefits of oral antioxidants are not clear even if studies have shown some positive effects on SDF. As excess supplementation may have a paradoxical effect on damage caused by oxidative stress, recommendations of antioxidants should be made with caution (50). Lifestyle interventions such as to quit smoking and to lose weight if obese, are on the contrary not associated with any negative effects but a positive measurable effect on SDF has not yet been demonstrated.

Short ejaculatory abstinence periods have been shown to produce ejaculates with a lower level of SDF as well as to improve the pregnancy outcomes after ICSI (82). Since SDF might be higher because of varicoceles, surgical repair can be considered for men with a large proportion of sperm with SDF and varicoceles (50). As high levels of SDF have a larger impact on the pregnancy outcomes of natural conception and IUI, ART with either IVF or ICSI is often the chosen treatment if natural conception fails to occur. 


\section{Aims}

The general aim of this thesis was to investigate the impact of non-optimal birth characteristics (small for gestational age, low birth weight, preterm birth and to a lesser extent large for gestational age) on infertility in men and if such an impact could be exerted, at least partly, by sperm DNA fragmentation.

Specific aims

- To evaluate whether men becoming fathers after assisted reproduction more often were born with non-optimal birth characteristics.

- To evaluate whether there was a difference between the need to apply conventional IVF or ICSI in relation to birth weight, gestational age at birth and size for gestational age in men who became fathers after assisted reproduction.

- To describe the birth characteristics of men in relation to their diagnosed factor of infertility and to compare the results of assisted reproduction between men with or without non-optimal birth characteristics and between men with different infertility factors.

- To investigate whether the decreased likelihood of becoming a parent previously reported in men born preterm, SGA, or with low birth weight was still present after additional 12 years of follow-up.

- To describe the relationships between preterm birth, low birth weight, and SGA, and infertility diagnoses and treatment in a Swedish setting.

- To compare two methods of analysing DNA fragmentation, SCSA and SCD (Halosperm ${ }^{\circledR} \mathrm{G} 2$ ) and to explore the status of DNA fragmentation in fertile sperm donors and men with unexplained infertility, and also to explore the DNA fragmentation before and after density gradient sperm selection.

- To investigate whether men with infertility and born SGA have a larger proportion of sperm with DNA fragmentation than men with infertility and born AGA. 


\begin{tabular}{|c|c|c|c|c|c|c|c|}
\hline &  & 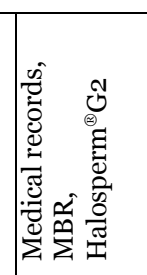 & 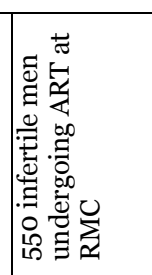 & I & 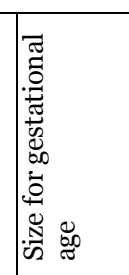 & 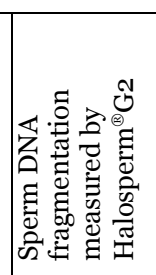 & 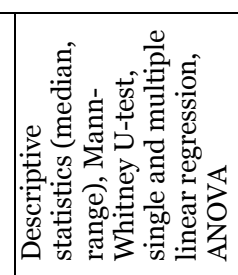 \\
\hline$z$ &  & 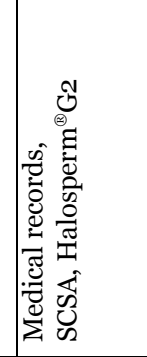 & 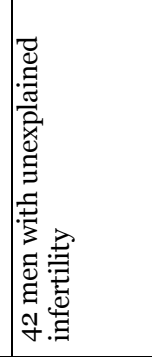 & 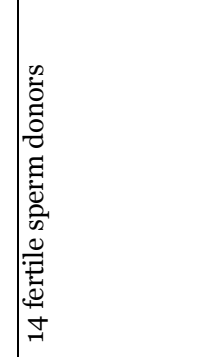 & 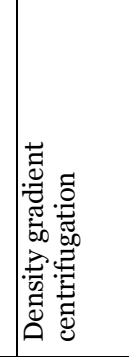 & 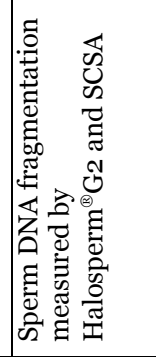 & 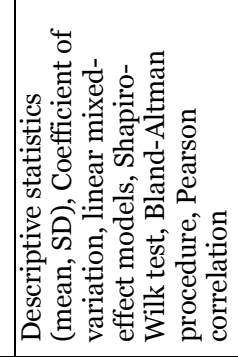 \\
\hline$\Xi$ & 1 & 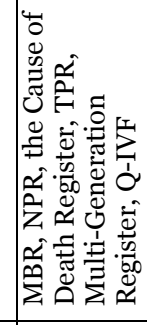 &  & I & 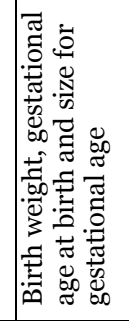 & 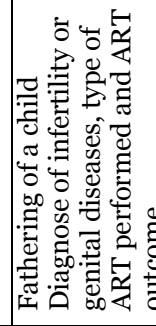 & 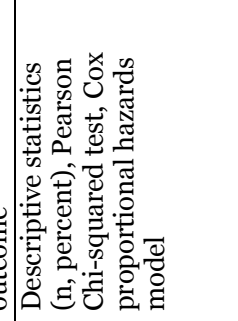 \\
\hline &  &  & 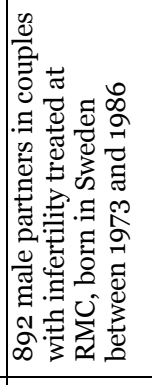 & 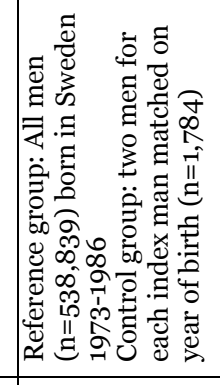 & 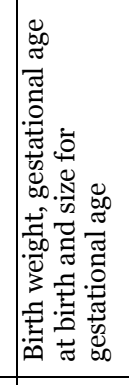 & 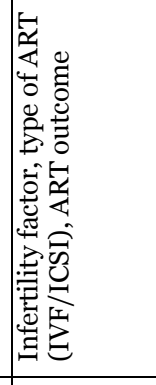 & 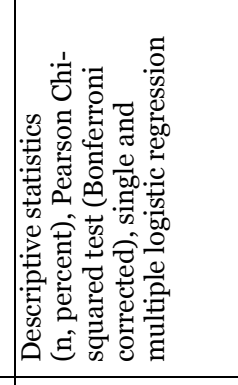 \\
\hline  &  & 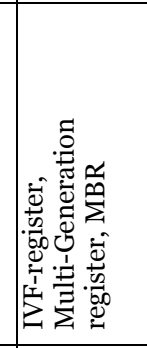 & 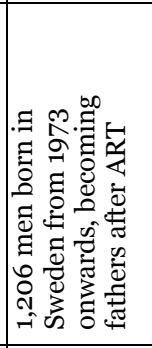 & 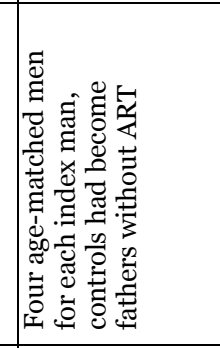 & 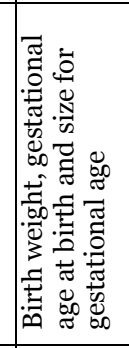 & 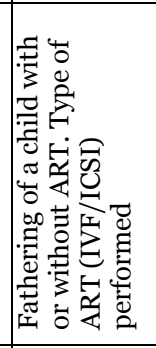 & 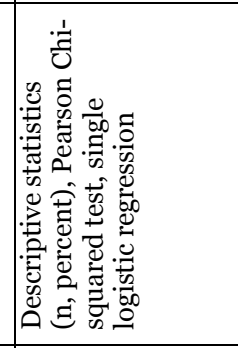 \\
\hline & & 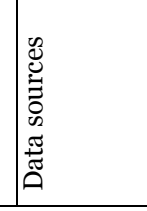 & 范 & 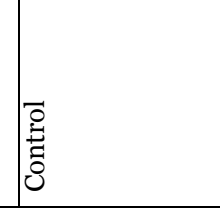 &  & 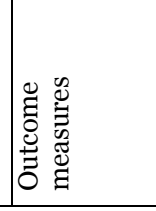 & 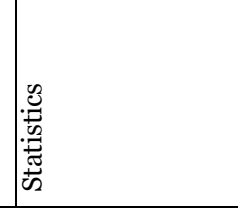 \\
\hline
\end{tabular}




\section{Material and methods}

An overview of the subjects and methods of the five studies was presented in table 2 on page 16 .

\section{Study population and design}

\section{Paper I}

Paper I is based on a retrospective case-control study of men becoming fathers after ART. Data on births up until 2007, in total 6,060, after successful ART where the mother was born from 1973 to 1983, were retrieved from the IVFregister. Fathers of 4,023 children could be identified using the MultiGeneration Register. For 1,206 of these fathers, data on birth characteristics could be obtained from the Medical Birth Register (MBR) as they were born in Sweden from 1973 and onwards. Gestational age at birth was known for 1,195 of the identified fathers. Information regarding ART method, conventional IVF or ICSI, was retrieved from the IVF-register.

The control group consisted of four age-matched men per index man, randomly selected from the Multi-Generation register. Men in the control group had become fathers without ART at the same age as the index men.

The birth characteristics of men becoming fathers after ART were compared with those of men conceiving without ART. Differences regarding birth characteristics were also described between men who became fathers after conventional IVF and men where ICSI had to be performed.

\section{Paper II}

Paper II is based on a retrospective case control study of male partners in couples diagnosed with infertility at the Centre of Reproductive Medicine (RMC), University Hospital, Linköping, Sweden. Results were compared with a reference and a control group. The couples were diagnosed and included between 2005 and 2010. 1,070 men consented to participate in the study and for 892 of them, information on birth weight and gestational age at birth could be retrieved from the MBR. Data on type of infertility factor, current smoking or use of snuff, weight, height, results from semen analyses, and treatments 
performed including outcome were obtained from medical charts and from questionnaires previously completed by patients.

The reference group consisted of all men born during the same period and their birth characteristics were retrieved from the MBR. From these MBR data, a control group of two men for each index man, matched on year of birth was constructed.

The birth characteristics of the men were described in relation to the factor of infertility and compared with birth characteristics of men in the reference and control group. Treatment outcomes and the use of conventional IVF or ICSI were described in relation to infertility factor and birth characteristics.

\section{Paper III}

Paper III is based on a register-based cohort study of all men born in Sweden between 1973 and 1993. Information on birth characteristics and diagnoses of infertility, undescended testicle(s), hypospadias, and genital cancer were obtained from the National Board of Health and Welfare (MBR and the National Patient Register respectively). To obtain information on the death of any of the men, date of death was retrieved from the Cause of Death Register. Information regarding parent-child relationships was provided by Statistics Sweden and the Total Population Register as well as the Multi-Generation Register. The Swedish National Quality Register of Assisted Reproduction provided information on ART treatments, including outcome. The following diagnoses from the International Classification of Diseases, tenth revision (ICD-10) were used: male infertility (N46), undescended testicle (Q53), hypospadias (Q54) and genital cancer (C60-63). Corresponding codes from the eighth and ninth revisions were also used. The men were followed until 2018.

Two cohorts, men born 1973-1983 and men born 1984-1993, were formed. The probability of becoming a father in relation to birth characteristics was described for the two cohorts. The reproductive rate of the oldest cohort was also compared with the reproductive rate for this particular cohort estimated in 2006. For both cohorts, infertility and genital diagnoses, and infertility treatments were described in relation to birth characteristics. 


\section{Paper IV}

Paper IV is based on a case series study with a study population of fertile semen donors $(n=14)$ and male patients $(n=42)$ undergoing ART treatment at RMC, Linköping University Hospital, Sweden between October 2016 and October 2017. All participants gave written informed consent. The patients were partners in an infertile couple with at least one year of unprotected intercourse where standard fertility investigations did not render in a plausible cause of the infertility and therefore was labelled unexplained. All participants provided a semen sample which was analysed for sperm DNA fragmentation by two methods, SCSA and SCD (Halosperm ${ }^{\circledR}$ G2). Samples from the infertile men were analysed before and after sperm selection with density gradient centrifugation. DNA fragmentation estimates were compared regarding method used, before and after density gradient centrifugation and between donors and patients.

\section{Paper V}

Paper V is based on a cohort study consisting of 550 men who were part of a couple undergoing ART treatment at RMC, Linköping University Hospital, Sweden, between October 2016 and December 2019. Data on birth characteristics were retrieved from MBR for all men in the study. Men born SGA constituted the index group. All men born AGA and included until June 2018, about 300 individuals, were considered the reference group.

Sperm DNA fragmentation (SDF) was analysed using Halosperm ${ }^{\circledR} \mathrm{G} 2$ in sperm samples after density gradient centrifugation from all men born SGA and compared with SDF median values for the reference group. The relation between total sperm count, age and SDF respectively was also reported. 
Table 3. Overview of registers used in the studies

\begin{tabular}{|c|c|c|c|}
\hline Register & Abbreviation & Description of Register & $\begin{array}{l}\text { Information } \\
\text { retrieved }\end{array}$ \\
\hline $\begin{array}{l}\text { The Swedish Medical } \\
\text { Birth Register } \\
\text { Held by the National } \\
\text { Board of Health and } \\
\text { Welfare }\end{array}$ & MBR & $\begin{array}{l}\text { Information on all } \\
\text { pregnancies that led to a } \\
\text { delivery in Sweden from } \\
\text { 1973, data on the mother } \\
\text { and the new-born infant }\end{array}$ & $\begin{array}{l}\text { Birth weight, } \\
\text { gestational age at } \\
\text { birth, diagnoses at } \\
\text { birth }\end{array}$ \\
\hline $\begin{array}{l}\text { The National Patient } \\
\text { Register } \\
\text { Held by the National } \\
\text { Board of Health and } \\
\text { Welfare }\end{array}$ & NPR & $\begin{array}{l}\text { Diagnoses after in-patient } \\
\text { care (since 1967, mandatory } \\
\text { since 1984), diagnoses after } \\
\text { out-patient doctor visits } \\
\text { (since 2001). Not primary } \\
\text { care. }\end{array}$ & $\begin{array}{l}\text { Diagnoses on male } \\
\text { infertility, genital } \\
\text { diseases, and } \\
\text { malformations in the } \\
\text { male reproductive } \\
\text { tract }\end{array}$ \\
\hline $\begin{array}{l}\text { The Cause of Death } \\
\text { Register } \\
\text { Held by the National } \\
\text { Board of Health and } \\
\text { Welfare }\end{array}$ & & $\begin{array}{l}\text { Deaths including cause of } \\
\text { deaths in all people } \\
\text { registered in the population } \\
\text { registry in Sweden since } \\
1961 .\end{array}$ & $\begin{array}{l}\text { Deaths before age } 13 \\
\text { (for exclusion) and } \\
\text { deaths for } \\
\text { participants (for exit } \\
\text { from model) }\end{array}$ \\
\hline $\begin{array}{l}\text { The Total Population } \\
\text { Register } \\
\text { Held by Statistics } \\
\text { Sweden }\end{array}$ & TPR & $\begin{array}{l}\text { Register of the population } \\
\text { in Sweden, based on data } \\
\text { from the population } \\
\text { registry from the Swedish } \\
\text { Tax Agency }\end{array}$ & $\begin{array}{l}\text { Men born 1973-1993 } \\
\text { in Sweden, marital } \\
\text { status }\end{array}$ \\
\hline $\begin{array}{l}\text { The Multigeneration } \\
\text { Register } \\
\text { Held by Statistics } \\
\text { Sweden }\end{array}$ & & $\begin{array}{l}\text { Register of persons born } \\
\text { after } 1932 \text { and at some time } \\
\text { registered in Sweden (index } \\
\text { persons) and their } \\
\text { biological and, if applicable, } \\
\text { adoptive parents. }\end{array}$ & $\begin{array}{l}\text { Identification of all } \\
\text { men becoming } \\
\text { fathers in Sweden } \\
\text { between 1986-2017 }\end{array}$ \\
\hline $\begin{array}{l}\text { The Swedish } \\
\text { National Quality } \\
\text { Register of Assisted } \\
\text { Reproduction }\end{array}$ & Q-IVF & $\begin{array}{l}\text { All assisted reproductive } \\
\text { technique treatments } \\
\text { performed in Sweden since } \\
2007\end{array}$ & $\begin{array}{l}\text { Follicle aspirations, } \\
\text { type of ART } \\
\text { performed, embryo } \\
\text { transfers, total } \\
\text { number of treatment } \\
\text { cycles, children born } \\
\text { after ART }\end{array}$ \\
\hline $\begin{array}{l}\text { The IVF Register } \\
\text { Held by the National } \\
\text { Board of Health and } \\
\text { Welfare }\end{array}$ & & $\begin{array}{l}\text { Register of children } \\
\text { conceived by ART } \\
\text { treatment in Sweden } \\
\text { between } 1982-2006\end{array}$ & $\begin{array}{l}\text { Children born after } \\
\text { ART, type of ART } \\
\text { performed }\end{array}$ \\
\hline
\end{tabular}




\title{
Data sources
}

\author{
Registers
}

An overview of the registers used in study I-III and V is presented in Table 3 on page 20.

\section{The Swedish Medical Birth Register}

Since 1973, information regarding prenatal, obstetrical, delivery and neonatal factors has been reported to the Swedish Medical Birth Register (MBR). In 1982, the data collection procedure was revised in order to minimise reporting errors and at the same time, information regarding diseases during pregnancies was included in the data collected. Additional changes have been made in 1990, 1994, and 1998. The register has a high coverage rate and contains information on $97-99 \%$ of pregnancies that resulted in a delivery in Sweden (83-85).

\section{The Swedish IVF-register}

The first child conceived by IVF treatment in Sweden was born in 1982. Since then and up until 2007, information on all children born after ART was reported to the National Board of Health and Welfare. A Swedish IVF-register was created in the mid-1990s with the approval of the Swedish Data Inspection Board. Almost every ART treatment resulting in the birth of a child was reported by all Swedish clinics performing ART. The intention of the register was to enable studies of possible health risks for children conceived by ART whereas information on treatments not leading to childbirth was not collected (86).

\section{The Swedish National Quality Register of Assisted Reproduction, Q-IVF}

All IVF clinics in Sweden, public as well as private, report to the Q-IVF register from 2007 onwards. The quality register contains information on treatment characteristics such as use of ICSI and donated gametes. Data on treatment outcomes such as pregnancies, deliveries but also treatment cycles not resulting in transferable embryos as well as miscarriages are also reported to the register (8). The coverage is high with only a few patients per year declining participation. 


\section{The National Patient Register}

This register, previously known as the Hospital Discharge Register, was established in 1964 and from 1987 data on all inpatient care are reported to the register. After a revision in 2001, all outpatient visits were included in the mandatory reporting. The purposes of the register are to track the changes in population health, to improve the possibilities to prevent and treat diseases, and to monitor and develop the quality of the Swedish health-care system. The coverage rate is about $99 \%$. The register contains information on age, sex, date of admission and discharge, as well as main and secondary diagnoses (87-89).

\section{The Cause of Death Register}

The register contains information on the cause of death of Swedish citizens and was established in 1961. Stillborn children are not included. The coverage rate is close to $100 \%$ but about $1-2 \%$ of the entries are incomplete $(90,91)$.

\section{Total Population Register}

The register was established in 1968 and contains information on births, deaths, migration, and changes in marital status. The register is held by Statistics Sweden and of good quality, although some over-coverage exits because of missing reports of emigration and deaths $(92,93)$.

\section{Multi-Generation Register}

The register is based on the Total Population Register and contains information on individuals born in 1932 or later and registered as living in Sweden at some time since 1961. The Multi-Generation Register makes it possible to identify an index person's biological or adoptive parents $(94,95)$. 


\section{Electronic medical records}

Data in paper II, IV, and V were collected from the computerized medical record system Cosmic $^{\circledR}$ (Cambio Health Care systems, Sweden). Cosmic ${ }^{\circledR}$ is the general medical record system for Region Östergötland, the main health care provider of the region.

Methods to Analyse Sperm DNA Fragmentation

\section{Sperm Chromatin Dispersion test, Halosperm ${ }^{\circledR} \mathrm{G} 2$}

HaloSpermG $2^{\circledR}$ (HalotechDNA, Madrid, Spain) is a commercial kit and was used for analyses of sperm DNA fragmentation (SDF), according to the instructions from the manufacturer.

In brief, the previously frozen sperm sample was thawed and $50 \mu \mathrm{L}$ of the sample was gently mixed with agarose (previously melted at $90^{\circ} \mathrm{C}$ and thereafter kept at $37^{\circ} \mathrm{C}$ ) in a tube. A drop of $8 \mu \mathrm{l}$ of the cell suspension was placed on a precoated glass slide and covered with a coverslip. Air bubbles formation was prevented by pressing gently. The slide was placed on a cold surface $\left(4^{\circ} \mathrm{C}\right)$ for 5 minutes to solidify the agarose. The coverslip was then removed, and the acid denaturation agent was applied and incubated for 7 minutes. The denaturant was removed by tilting the slide, without shaking, and the lysis solution was applied. After 20 minutes of incubation, the lysis solution was removed by tilting and the slide was washed with abundant distilled water for 5 minutes. The slide was dehydrated with $70 \%$ ethanol for 2 minutes and then with $100 \%$ ethanol for another 2 minutes. After drying, the drop was stained with eosin for 7 minutes followed by thiazine staining for additional 7 minutes. The excess of staining was removed, and the slide allowed to dry at room temperature.

Visualization was performed in an inverted bright field microscope (LEICA D100, Stockholm, Sweden). A minimum of 200 spermatozoa per sample were scored at $\mathrm{x} 400$ magnification. The percentage of sperm with fragmented DNA was calculated by dividing the fragmented + degraded spermatozoa by the total number of counted cells (x100). A positive control was performed by not adding the denaturant agent, and all spermatozoa were shown with halo. A negative control was performed by not adding the lysis solution, and all spermatozoa lacked halo. 


\section{Sperm Chromatin Structure Assay, SCSA}

The SCSA procedure protocol followed the description of Evenson $(96,97)$. In brief, $400 \mu \mathrm{L}$ of acid detergent $(\mathrm{NaCl} 150 \mathrm{mM}$, Triton $\mathrm{X}-100 \mathrm{0.1} \% \mathrm{v} / \mathrm{v}$ and $\mathrm{HCl}$ $80 \mathrm{mM})$ was added to the thawed sperm sample $(200 \mu \mathrm{L})$ in a pre-cooled cytometer tube. After exactly $30 \mathrm{~s}, 1.2 \mathrm{~mL}$ of acridine orange solution (Citric acid $33.4 \mathrm{mM}, \mathrm{Na}_{2} \mathrm{HPO}_{4} 132.3 \mathrm{mM}, \mathrm{NaCl} 150 \mathrm{mM}$, EDTA $1 \mathrm{mM}$, acridine orange 6 $\mathrm{mg} / \mathrm{L}$; pH6) was added. All samples from donors and patients were analysed at the same time. Gallios flow cytometer (Beckman Coulter, Bromma, Sweden) with standard optics with argon laser (488nm, blue) excitation was used when analysing the sperm suspensions. The filter configuration was as follows: FL1 550 SP 525BP for green fluorescence and FL3 655SP 620/30 for red fluorescence. 5,000 events were assessed per sample, with a flow rate of 200250 cells/s. The instrument was controlled via the Navios software (Beckman Coulter, Bromma, Sweden) and analyses of acquired data were performed with Kaluza software (Beckman Coulter, Bromma, Sweden). The ratio of red/red + green fluorescence (DNA fragmentation index, DFI, \%) was calculated in Renvironment as well as the proportion of immature spermatozoa with proposed defects in histone-to-protamine transition (High DNA Stability, HDS, in \%). TNE buffer: Tris- $\mathrm{HCl} 10 \mathrm{mM}, \mathrm{NaCl} 150 \mathrm{mM}$ and EDTA 1mM; $\mathrm{pH}$ 7.4. 


\section{Statistics}

\section{Descriptive statistics}

For categorical variables, the number and percentages were presented (paper I, II and III). For continuous variables, mean and standard deviations were presented in paper IV but due to the small sample size in paper V, median and range were presented instead.

\section{Pearson Chi-square}

To compare categorical variables in paper I, II and III, Pearson Chi-squared test was used and a two-sided p-value of $<0.05$ was considered statistically significant. In paper II, the model is Bonferroni adjusted because of multiple calculations.

\section{Regression}

The regression model can identify the strength of the effect that the independent variable(s) have on a dependent variable, and it can be used to forecast effects of changes in the independent variable. Regression analysis can also predict future values. When the dependent variable is continuous, linear regression model should be used. With one independent variable single linear regression is used, and with two or more independent variables, multiple linear regression is used instead. Both single and multiple linear regression were used in paper $\mathrm{V}$ to assess the relationships between age, total sperm count and sperm DNA Fragmentation (SDF). In paper IV a linear mixed-effect model was used when comparing two different methods of analysing SDF as it allows both fixed effects and random effects.

The logistic regression model predicts the odds ratio (OR) of the studied event happening when the dependent variable is categorical. The model can also be separated into two types: single and multiple regression. Single logistic regression is used when there is one independent variable that can be either categorical or continuous, and when there are two or more independent variables multiple logistic regression must be used. 
Logistic regression was used in paper I to calculate the OR of being born preterm, SGA or with LBW for men becoming fathers through ART and for men where ICSI had to be performed. In paper II, the model was used to calculate the OR of being born preterm, SGA or with LBW for men with different infertility factors. Both the crude OR and the OR adjusted for suspected covariates/confounders, i.e., smoking and BMI, were presented.

Cox proportional hazards model

The Cox proportional hazards model is a regression model commonly used in medical research for investigating the association between the survival time of patients and one or more predictor variables. The predictor variables, or covariates, influence the rate of a particular event happening at a particular point in time and the rate is commonly referred to as the hazard rate (HR). The model allows the study subject to exit before the studied event happens, and to enter the study at different time-points. Estimates of the HR will take this into account.

In paper III, the model was used to evaluate the association between being born with non-optimal birth characteristics and the likelihood of becoming a father within the follow-up period. Time to event was defined as the age of becoming a father for the first time. Men left the model when becoming a father, at the time of emigrating, at the time of death, or when reaching the end of the follow-up period, depending on which of these events was the first event to occur.

\section{Coefficient of variation}

The coefficient of variation (CV) is also known as relative standard deviation and is defined as the ratio of the standard deviation to the mean. When comparing results from two different methods, as in paper IV where sperm DNA fragmentation as estimated by SCSA was compared to estimations made by Halosperm ${ }^{\circledR} \mathrm{G} 2$, the CV is considered more useful than standard deviation.

\section{Pearson Correlation}

This bivariate test produces a sample correlation coefficient, $r$, which measures the strength and direction of linear relationships between continuous variables. The correlation between sperm DNA fragmentation estimated with 
Halosperm ${ }^{\circledR} \mathrm{G} 2$, SDF, and estimated with SCSA, DFI, was shown to be positive and strong $(\mathrm{r}=\mathrm{0.82}, \mathrm{p}<0.05)$ as determined by Pearson correlation test in paper IV.

\section{Bland-Altman procedure}

The Bland-Altman plot method (BA) is used to assess the agreement between two measurement methods (98). Correlation should be high between two methods designed to measure the same parameter and does not necessarily imply a good agreement between the methods. The graph illustrating results from BA is a scatter plot $\mathrm{XY}$. The $\mathrm{Y}$ axis shows the difference between the two paired measurements and the $\mathrm{X}$ axis shows the average (mean) of these measures. The most common way to plot the BA method is to compute $95 \%$ limits of agreement (average difference \pm 1.96 standard deviation of the difference). In paper IV, the BA method was used to illustrate that the methods compared, SCSA and Halosperm ${ }^{\circledR}$ G2, were both effective in measuring DNA fragmentation in spermatozoa.

\section{Mann-Whitney U-test}

To test for differences regarding age, total sperm count and sperm DNA fragmentation between men born SGA and men born AGA in paper V, MannWhitney U-test was performed. The sample size was not large enough to allow for a parametric test as only 6 individuals in the study were born SGA.

\section{ANOVA}

Analysis of Variance (ANOVA) is a method to assess differences in a continuous dependent variable by a nominal-level independent variable having two or more categories. Differences in SDF between men with female, male, combined or unexplained factor infertility were evaluated with ANOVA in paper $\mathrm{V}$. 


\section{Ethical approval and considerations}

The studies in this thesis were approved by the Regional Ethical Review Board in Linköping (Study I: M233-08 and 2010/403-31; Study II: 03-556, 07-M6608, o8-M233-08, and 2014-112/31; Study III: 03-556, 07-M66-08, o8-M23308, and 2017/513-31; Study IV: 2010/398-31, 2013/103-31, 2013/344-32, and 2015/387-31 and Study V: 2015/387-31, and 2017/513-31)

Overall, the studies were performed according to the declaration of Helsinki (99). Population-based registers held by the National Board of Health and Welfare and Statistics Sweden are known for their high quality and are widely used in medical research. The agencies require ethical approval to provide access to data, but each agency must also ensure that current ethical principles and Swedish legislation will not be violated prior to delivering data to the researcher. Data from population-based registers were obtained for study I, II, III and V. Individuals in these registers have no possibility to either approve or disapprove to the usage of their information in research.

Research with data from population-based registers includes persons without their individual consent and one can argue if this is in line with the principles of research ethics. As most of these epidemiological studies could not be performed if each subject had to consent, the public benefits are often considered important enough to allow access to register data. This must be considered and approved by the Regional Ethical Review Board upon the application made by the researchers.

The results are reported on a group level, enabling the maintenance of patient integrity. The risk of identifying individuals is larger when the outcome is rare and must be addressed by the researcher.

The participation in quality registers, like Q-IVF used in study III, is not mandatory. Very few patients undergoing ART decide not to consent to participation and the register covers almost all treatment cycles performed in Sweden. All ART treatments performed in Swedish clinics are reported to the Health and Social Care Inspectorate (IVO), but the data are anonymised and identification of patients is not possible.

Written informed consent was obtained from all study subjects in study II, IV and V. The participants had the right to withdraw their consent at any time without giving a reason. Persons participating in study IV and V were at the same time patients going through ART treatments. The total number or type of treatment (conventional IVF or ICSI) offered were not affected by participation in the study, nor by withdrawal of consent. 
The semen samples in study IV and V were handled according to the regulation of Biobanks regarding biological samples in research and the local regulation used by the Health Care authorities of Region Östergötland. The samples were coded and the key code to the personal identity number is securely maintained at Region Östergötland. 


\section{Results and comments}

\section{Main findings of study I}

The study consisted of 1,206 fathers after either conventional IVF or ICSI and a control group of 4 age-matched men for each index man. Men in the control group became fathers at the same age as the index man.

Couples decide to go through an ART treatment for several reasons. As this was a register study based on successful ART treatments that led to the birth of a child, the indication of the treatment performed was not known. When the infertility is caused by a male factor with semen parameters below normal, ICSI is often performed instead of conventional IVF. ICSI is also often performed if the fertilisation rate in a previous IVF cycle was low, regardless of semen parameters. Treatments with ICSI were therefore considered as a proxy for male factor infertility, or as an indication of preceding unsuccessful fertilisation with conventional IVF.

Fathers after ART were more often born with LBW (4.1\%) compared with men who became fathers after natural conception $(2.5 \%), p=0.048$. This is equivalent with an OR of being born with LBW of 1.66 (95\% CI 1.17-2.36.) The likelihood of being born SGA (OR 1.10, 95\% CI 0.79- 1.52) or preterm (OR 1.32, 95\% CI 1.00-1.77) was not significantly increased.

Men becoming fathers after ICSI had an increased likelihood of being born SGA both compared with controls (OR 1.54, 95\% CI 1.04-2.30) and compared with men becoming fathers after IVF (OR 2.12, 95\% CI 1.17-3.83), while there was no difference in likelihood of being born SGA between IVF-fathers and controls (OR 0.73, 95\% CI $0.44-1.20$ ). ICSI was needed for $63 \%$ of the men born SGA, but only for $45 \%$ of the men born AGA ( $\mathrm{p}=0.001)$. Fathers after IVF were more often born LGA (3.5\%) than ICSI-fathers (1.5\%), $\mathrm{p}=0.035$.

\section{Main findings of study II}

The subjects in study II were men with infertility, i.e., male partners in couples who had not achieved a pregnancy after more than 12 months of unprotected intercourse. All men were diagnosed with an infertility factor together with their female partner, either female, male, combined or unexplained. 
The study consisted of 892 men for whom infertility factor, birth weight, gestational age at birth, and size for gestational age were known. Almost one third of the men $(n=289,32.3 \%)$ diagnosed at the infertility clinic did not undergo any treatments. The reasons for not continuing with IVF treatments were not known. Azoospermia was discovered in 61 men, 6.8\%. Men who had previously undergone sterilization were not included in the study.

The median year of birth was 1976 with a range from 1973 to 1986 and the men were thus between 29 and 37 years at the time of inclusion. The median year of birth was the same for men with different infertility factors apart from men with unexplained infertility whose median age of birth was one year earlier, 1975.

There were no differences regarding Body Mass Index (BMI) among men with different infertility factors. The proportion of overweight and obese men with infertility, $52.0 \%$, was roughly the same as the proportion in the total male population in the region at that time, $52-58 \%$, even if the men in the population data set were older as they were between 16 and 84 years at time of survey. Men born SGA in the study population were not more often overweight or obese as $51.5 \%$ of them had a BMI over 25 .

Smoking habits did not differ between men with different infertility factors, $5.2 \%$ were habitual smokers. Smoking was less common in these men than in the population as about $12 \%$ of men aged 30-39 were daily smokers (100). Men with male or combined infertility did not use snuff to the same extent as men with female or unexplained infertility. In the group of men with male factor infertility $19.9 \%$ used snuff, with combined factors $20.2 \%$, with female factor $28.9 \%$, and in the group of men with unexplained infertility $31.8 \%$ used snuff $(\mathrm{p}=0.04)$. The proportion of habitual snuff-users among men in the total population aged $30-39$ years in 2008-2011 was about $25 \%$ (101).

Men with male factor infertility were mere often born SGA, preterm or with LBW than men in the reference group, (12.1\% vs. $8.8 \%, p=0.004)$. In the control group, $8.2 \%$ were born SGA, preterm or with LBW $(\mathrm{p}=0.08)$. The prevalence of male factor infertility in the infertile men was $42.6 \%$, but $55.2 \%$ of the men born SGA had male factor infertility and $52.9 \%$ of men born with LBW, although the differences were not statistically significant.

The likelihood of being born SGA and/or with LBW was higher for men with male factor infertility compared with other infertility diagnoses, with OR adjusted for BMI and smoking over 1.0 (range 1.06 to 4.84, see table 4) for all comparisons. The $95 \%$ confidence intervals included 1.0 in most of the 
comparisons indicating a lack of power. The likelihood of being born preterm was not higher for men with male factor infertility as ORs ranged from 0.53 to 1.36 (table 4).

Table 4. The likelihood for non-optimal birth characteristics among different diagnosed factors of infertility

\begin{tabular}{|c|c|c|c|c|c|}
\hline & $\begin{array}{c}\text { Male vs. } \\
\text { unexplained }\end{array}$ & $\begin{array}{c}\text { Combined } \\
\text { vs. } \\
\text { unexplained }\end{array}$ & $\begin{array}{c}\text { Male + } \\
\text { combined vs. } \\
\text { unexplained }\end{array}$ & $\begin{array}{l}\text { Male vs. } \\
\text { female }\end{array}$ & $\begin{array}{c}\text { Male }+ \\
\text { combined vs. } \\
\text { female }\end{array}$ \\
\hline & $\begin{array}{c}\mathrm{aOR} \\
(95 \% \mathrm{CI})\end{array}$ & $\begin{array}{c}\mathrm{aOR} \\
(95 \% \mathrm{CI})\end{array}$ & $\begin{array}{c}\mathrm{aOR} \\
(95 \% \mathrm{CI})\end{array}$ & $\begin{array}{c}\mathrm{aOR} \\
(95 \% \mathrm{CI})\end{array}$ & $\begin{array}{c}\mathrm{aOR} \\
(95 \% \mathrm{CI})\end{array}$ \\
\hline $\begin{array}{l}\text { PTB } \\
\text { Yes }\end{array}$ & $\begin{array}{c}0.66 \\
(0.23-1.86)\end{array}$ & $\begin{array}{c}1.36 \\
(0.58-3.20)\end{array}$ & $\begin{array}{c}1.25 \\
(0.54-2.90)\end{array}$ & $\begin{array}{c}0.53 \\
(0.20-1.38)\end{array}$ & $\begin{array}{c}0.88 \\
\left(0.45^{-1.70}\right)\end{array}$ \\
\hline No & Reference & Reference & Reference & Reference & Reference \\
\hline $\begin{array}{l}\text { LBW } \\
\text { Yes }\end{array}$ & $\begin{array}{c}1.08 \\
(0.33-3.53)\end{array}$ & $\begin{array}{c}1.62 \\
(0.56-4.68)\end{array}$ & $\begin{array}{c}2.11 \\
(0.70-6.42)\end{array}$ & $\begin{array}{c}1.06 \\
(0.36-3.14)\end{array}$ & $\begin{array}{c}1.37 \\
(0.60-3.15)\end{array}$ \\
\hline No & Reference & Reference & Reference & Reference & Reference \\
\hline $\begin{array}{l}\text { SGA } \\
\text { Yes }\end{array}$ & $\begin{array}{c}4.84 \\
(1.32-17.80)\end{array}$ & $\begin{array}{c}2.15 \\
(0.53-8.78)\end{array}$ & $\begin{array}{c}2.98 \\
\text { (o.86-10.39) }\end{array}$ & $\begin{array}{c}1.84 \\
(0.76-4.47)\end{array}$ & $\begin{array}{c}1.24 \\
(0.56-2.77)\end{array}$ \\
\hline No & Reference & Reference & Reference & Reference & Reference \\
\hline
\end{tabular}

The unadjusted ORs for non-optimal birth characteristics were all different compared with the results adjusted for BMI and smoking (for all unadjusted results, see Liffner et al., 2020 (102). Crude ORs for SGA were lower for all infertility factors except male + combined vs. female factors, where it was slightly higher.

In this clinical sample of men with infertility, no differences in numbers of pregnancies or children born after treatment could be found between men with different infertility factors. As expected, ICSI was more often used when treating men with male factor infertility than men with female factor or unexplained infertility, $\mathrm{p}<0.001$. ICSI was used at least once for $18.8 \%$ of men with unexplained infertility, for $28.2 \%$ of men with female factor, for $62.5 \%$ of men with male factor and for $51.1 \%$ of men with combined factor infertility. Being born with non-optimal birth characteristics did not affect the rates of either pregnancies or live births after ART. 


\section{Main findings of study III}

In this study of 1,045,167 men, $46.6 \%$ of them had become fathers in the end of 2017. Results were reported separately for two cohorts, an older cohort that consisted of men born between 1973 and 1983, and a younger cohort of men born between 1984 and 1993. The probability of becoming a father had previously been estimated in 2006 for the older cohort and was then found to be lower for men born preterm, SGA, and/or with LBW. The probability of reproducing could in this study be estimated up until 2018 and was compared with the probability 12 years earlier. It was also compared with the probability for men in the younger cohort as they were about the same age in 2017 as the men in the older was in 2006. The probability of reproducing for men with nonoptimal birth characteristics could therefore in this study both be evaluated after a longer follow-up time and evaluated in relation to year of birth.

Men born SGA or with LBW had a decreased likelihood of becoming a father compared with men born with normal birth characteristics as shown in table 5 . The likelihood of reproducing had not increased for men in the older cohort. The younger cohort of men born SGA or with LBW had a slightly higher likelihood to become fathers than their older counterparts, both when investigated at a similar age and when comparing the likelihood in 2018. Whether PTB affects the likelihood of reproducing was less clear as the confidence intervals overlapped 1.0.

Table 5. Hazard ratios of reproducing and corresponding 95\% confidence intervals

\begin{tabular}{|c|c|c|c|c|c|c|}
\hline \multirow[b]{2}{*}{ Cohort } & \multicolumn{2}{|c|}{ SGA } & \multicolumn{2}{|c|}{ PTB } & \multicolumn{2}{|c|}{ LBW } \\
\hline & HR (95\%CI) & p-value & $\mathrm{HR}(95 \% \mathrm{CI})$ & $\begin{array}{c}\mathrm{p}- \\
\text { value }\end{array}$ & $\mathrm{HR}(95 \% \mathrm{CI})$ & $\begin{array}{c}\text { p- } \\
\text { value }\end{array}$ \\
\hline $\begin{array}{l}\text { Total } \\
\text { sample }\end{array}$ & $\begin{array}{c}0.91 \\
(0.90-0.92)\end{array}$ & $<0.001$ & $\begin{array}{c}0.85 \\
\text { (0.74-0.98) }\end{array}$ & 0.025 & $\begin{array}{c}0.88 \\
\text { (0.86-0.90) }\end{array}$ & $<0.001$ \\
\hline $\begin{array}{l}1973^{-} \\
1983\end{array}$ & $\begin{array}{c}0.90^{*} \\
(0.89-0.92)\end{array}$ & $<0.001$ & $\begin{array}{c}0.86^{*} \\
\left(0.73^{-1.02)}\right.\end{array}$ & 0.082 & $\begin{array}{c}0.86^{*} \\
\text { (o.84-0.88) }\end{array}$ & $<0.001$ \\
\hline & $\begin{array}{c}0.91^{* *} \\
(0.88-0.94)\end{array}$ & $<0.001$ & $\begin{array}{c}0.94^{* *} \\
(0.91-0.97)\end{array}$ & $<0.001$ & $\begin{array}{c}0.89^{* *} \\
(0.86-0.92)\end{array}$ & $<0.001$ \\
\hline $\begin{array}{l}1984- \\
1993\end{array}$ & $\begin{array}{c}0.92 \\
(0.89-0.95)\end{array}$ & $<0.001$ & $\begin{array}{c}0.83 \\
(0.64-1.08)\end{array}$ & 0.167 & $\begin{array}{c}0.94 \\
(0.90-0.97)\end{array}$ & 0.001 \\
\hline
\end{tabular}

Data from the cohort born $1973-1983$ analysed $2018^{*}$ and $2006^{* *}$. Data from $2006^{* *}$ has previously been published by deKeyser et al 2012 . 
By the end of 2017, 68.8\% of the men in the older cohort had become fathers and $24.9 \%$ in the younger. In $2006,26.4 \%$ of the men had become fathers, then being about as old as the younger cohort in 2017. In the older cohort, men who had not become fathers were more often born preterm, SGA, and/or with LBW (see table 6). The childless men in the younger cohort were more often born SGA and/or with LBW than men born AGA, but not as often as the childless men in the older cohort. Childless men in the younger cohort were not born prematurely as often as men who had become fathers (see table 7).

Table 6. Non-optimal birth characteristics in fathers and childless men, older cohort

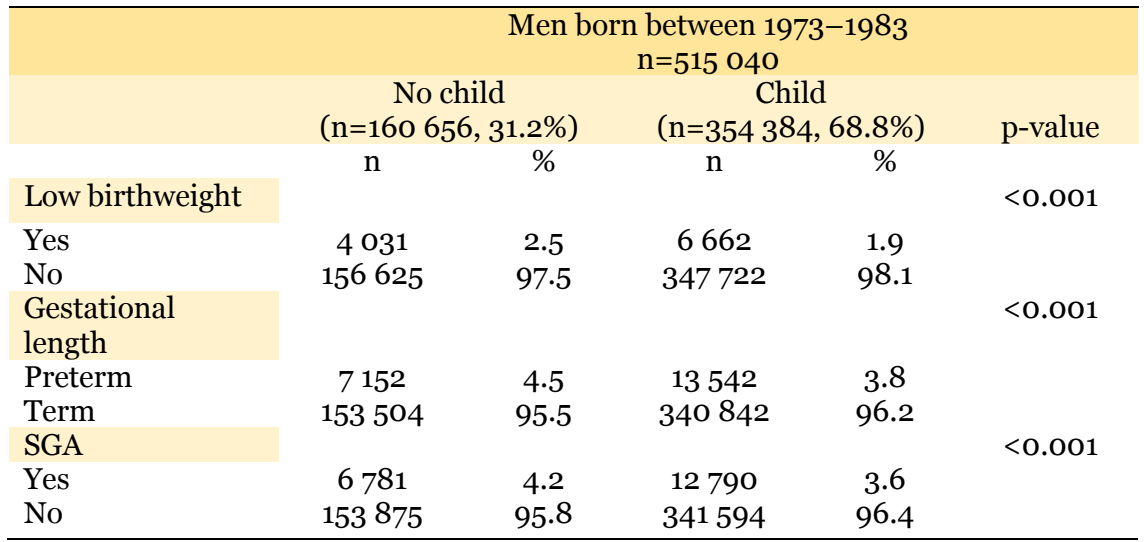

Table 7. Non-optimal birth characteristics in fathers and childless men, younger cohort

\begin{tabular}{|c|c|c|c|c|c|}
\hline \multirow[b]{4}{*}{ Low birthweight } & \multicolumn{5}{|c|}{$\begin{array}{l}\text { Men born between 1984-1993 } \\
n=530127\end{array}$} \\
\hline & \multicolumn{2}{|c|}{$\begin{array}{c}\text { No child } \\
(\mathrm{n}=397980,75.1 \%)\end{array}$} & \multicolumn{2}{|c|}{$\begin{array}{c}\text { Child } \\
(\mathrm{n}=132147,24.9 \%)\end{array}$} & \multirow[t]{2}{*}{$\mathrm{p}$-value } \\
\hline & $\mathrm{n}$ & $\%$ & $\mathrm{n}$ & $\%$ & \\
\hline & & & & & 0.011 \\
\hline Yes & 8597 & 2.2 & 2701 & 2.0 & \\
\hline No & 389383 & 97.8 & 129446 & 98.0 & \\
\hline $\begin{array}{l}\text { Gestational } \\
\text { length }\end{array}$ & & & & & 0.017 \\
\hline Preterm & 17704 & 4.4 & 6085 & 4.6 & \\
\hline Term & 380276 & 95.6 & 126062 & 95.4 & \\
\hline SGA & & & & & $<0.001$ \\
\hline Yes & 9733 & 2.4 & 3028 & 2.3 & \\
\hline No & 388247 & 97.6 & 129119 & 97.7 & \\
\hline
\end{tabular}


Fathers in both age cohorts had more often been diagnosed with infertility than men who had not fathered a child $(6.0 \%$ vs. $3.4 \%$, p $<0.001$ in the older cohort; $3.1 \%$ vs. $0.8 \%, \mathrm{p}<0.001$ in the younger).

A larger proportion of men born SGA, preterm and/or with LBW were single compared with men born AGA at term, p<0.001. Men with non-optimal birth characteristics had also more often been diagnosed with undescended testicle(s) and hypospadias even if differences in absolute numbers were small. Genital cancers were not more common.

Table 8. Marital status and diseases in relation to birth characteristics, older cohort

\begin{tabular}{|c|c|c|c|c|c|c|c|c|c|}
\hline & \multicolumn{9}{|c|}{$\begin{array}{l}\text { Men born between } 1973-1983 \\
n=515040\end{array}$} \\
\hline & \multicolumn{2}{|c|}{ SGA } & & \multicolumn{2}{|c|}{ Preterm } & \multicolumn{3}{|c|}{ LBW } & \\
\hline & $\begin{array}{l}\text { Yes } \\
\mathrm{n}(\%)\end{array}$ & $\begin{array}{l}\text { No } \\
\text { n (\%) }\end{array}$ & p-value & $\begin{array}{l}\text { Yes } \\
\text { n (\%) }\end{array}$ & $\begin{array}{l}\text { No } \\
\text { n (\%) }\end{array}$ & p-value & $\begin{array}{l}\text { Yes } \\
\mathrm{n}(\%)\end{array}$ & $\begin{array}{l}\text { No } \\
\text { n (\%) }\end{array}$ & p-value \\
\hline $\begin{array}{l}\text { Marital } \\
\text { status }\end{array}$ & & & $<0.001$ & & & $<0.001$ & & & $<0.001$ \\
\hline Married & $\begin{array}{l}15516 \\
(79.5)\end{array}$ & $\begin{array}{c}410848 \\
(83.1)\end{array}$ & & $\begin{array}{l}16384 \\
(79.4)\end{array}$ & $\begin{array}{l}409980 \\
(83.1)\end{array}$ & & $\begin{array}{l}8385 \\
(78.7)\end{array}$ & $\begin{array}{c}417979 \\
(83.1)\end{array}$ & \\
\hline Cohabiting & $\begin{array}{l}2204 \\
(11.3)\end{array}$ & $\begin{array}{c}48645 \\
(9.8)\end{array}$ & & $\begin{array}{l}2362 \\
(11.4)\end{array}$ & $\begin{array}{c}48487 \\
(9.8)\end{array}$ & & $\begin{array}{l}1204 \\
(11.3)\end{array}$ & $\begin{array}{c}49645 \\
(9.9)\end{array}$ & \\
\hline Single & $\begin{array}{l}1794 \\
(9.2)\end{array}$ & $\begin{array}{c}34822 \\
(7.0)\end{array}$ & & $\begin{array}{l}1897 \\
(9.2)\end{array}$ & $\begin{array}{c}34719 \\
(7.0)\end{array}$ & & $\begin{array}{l}1068 \\
(10.0)\end{array}$ & $\begin{array}{c}35548 \\
(7.1)\end{array}$ & \\
\hline $\begin{array}{l}\text { Undescended } \\
\text { testicle(s) }\end{array}$ & & & 0.001 & & & 0.025 & & & $<0.001$ \\
\hline Yes & $\begin{array}{c}25 \\
(0.1)\end{array}$ & $\begin{array}{c}319 \\
(0.1)\end{array}$ & & $\begin{array}{c}22 \\
(0.1)\end{array}$ & $\begin{array}{c}322 \\
(0.1)\end{array}$ & & $\begin{array}{c}17 \\
(0.2)\end{array}$ & $327(0.1)$ & \\
\hline No & $\begin{array}{l}19546 \\
(99.9)\end{array}$ & $\begin{array}{l}495150 \\
(99.9\end{array}$ & & $\begin{array}{l}20672 \\
(99.9)\end{array}$ & $\begin{array}{l}494924 \\
(99.9)\end{array}$ & & $\begin{array}{l}10676 \\
(99.8)\end{array}$ & $\begin{array}{l}504020 \\
(99.9)\end{array}$ & \\
\hline Hypospadias & & & $<0.001$ & & & 0.019 & & & $<0.001$ \\
\hline Yes & $\begin{array}{l}20 \\
(0.0)\end{array}$ & $\begin{array}{l}136 \\
(0.0)\end{array}$ & & $\begin{array}{c}12 \\
(0.1)\end{array}$ & $\begin{array}{c}144 \\
(0.0)\end{array}$ & & $\begin{array}{c}14 \\
(0.1)\end{array}$ & $142(0.0)$ & \\
\hline No & $\begin{array}{l}19551 \\
(99.9)\end{array}$ & $\begin{array}{l}495333 \\
(100.0)\end{array}$ & & $\begin{array}{c}20862 \\
(99.9)\end{array}$ & $\begin{array}{c}494202 \\
(100.0)\end{array}$ & & $\begin{array}{l}10679 \\
(99.9)\end{array}$ & $\begin{array}{c}504020 \\
(99.9)\end{array}$ & \\
\hline $\begin{array}{l}\text { Genital } \\
\text { cancers }\end{array}$ & & & 0.348 & & & 0.697 & & & 0.189 \\
\hline Yes & $\begin{array}{c}93 \\
(0.5)\end{array}$ & $\begin{array}{l}2132 \\
(0.4)\end{array}$ & & $\begin{array}{c}93 \\
(0.4)\end{array}$ & $\begin{array}{l}2132 \\
(0.4)\end{array}$ & & $\begin{array}{l}55 \\
(0.5)\end{array}$ & $\begin{array}{l}2170 \\
(0.4)\end{array}$ & \\
\hline No & $\begin{array}{c}19478 \\
(99.5)\end{array}$ & $\begin{array}{c}493337 \\
(99.6)\end{array}$ & & $\begin{array}{c}20601 \\
(99.6)\end{array}$ & $\begin{array}{c}492214 \\
(99.6)\end{array}$ & & $\begin{array}{c}10638 \\
(99.5)\end{array}$ & $\begin{array}{c}502177 \\
(99.6)\end{array}$ & \\
\hline
\end{tabular}


Table 9. Marital status and diseases in relation to birth characteristics, younger cohort

\begin{tabular}{|c|c|c|c|c|c|c|c|c|c|}
\hline & & & & Men bol & $\begin{array}{l}\text { between } \\
\mathrm{n}=530127\end{array}$ & $84-1993$ & & & \\
\hline & & $\mathrm{BA}$ & & & erm & & & & \\
\hline & $\begin{array}{c}\text { Yes } \\
\text { n (\%) }\end{array}$ & $\begin{array}{c}\text { No } \\
\text { n (\%) }\end{array}$ & p-value & $\begin{array}{c}\text { Yes } \\
\text { n (\%) }\end{array}$ & $\begin{array}{c}\text { No } \\
\text { n (\%) }\end{array}$ & p-value & $\begin{array}{c}\text { Yes } \\
\text { n (\%) }\end{array}$ & $\begin{array}{c}\text { No } \\
\text { n (\%) }\end{array}$ & p-value \\
\hline Marital status & & & $<0.001$ & & & $<0.001$ & & & $<0.001$ \\
\hline Married & $\begin{array}{l}7858 \\
(61.7)\end{array}$ & $\begin{array}{c}344145 \\
(66.7)\end{array}$ & & $\begin{array}{l}15291 \\
(64.4)\end{array}$ & $\begin{array}{c}336712 \\
(66.6)\end{array}$ & & $\begin{array}{l}6954 \\
(61.7)\end{array}$ & $\begin{array}{c}345049 \\
(66.6)\end{array}$ & \\
\hline Cohabiting & $\begin{array}{l}2099 \\
(16.5)\end{array}$ & $\begin{array}{l}75613 \\
(14.6)\end{array}$ & & $\begin{array}{l}3725 \\
(15 \cdot 7)\end{array}$ & $\begin{array}{c}73987 \\
(14.6)\end{array}$ & & $\begin{array}{l}1913 \\
(17.0)\end{array}$ & $\begin{array}{l}75799 \\
(14.6)\end{array}$ & \\
\hline Single & $\begin{array}{l}2774 \\
(21.8)\end{array}$ & $\begin{array}{c}96669 \\
(18.7)\end{array}$ & & $\begin{array}{l}4726 \\
(19.9)\end{array}$ & $\begin{array}{l}94717 \\
(18.7)\end{array}$ & & $\begin{array}{l}2405 \\
(21.3)\end{array}$ & $\begin{array}{c}97038 \\
(18.7)\end{array}$ & \\
\hline $\begin{array}{l}\text { Undescended } \\
\text { testicle(s) }\end{array}$ & & & $<0.001$ & & & 0.001 & & & $<0.001$ \\
\hline Yes & $\begin{array}{l}142 \\
(1.1)\end{array}$ & $\begin{array}{l}2942 \\
(0.6)\end{array}$ & & $\begin{array}{l}177 \\
(0.7)\end{array}$ & $\begin{array}{l}2907 \\
\text { (0.6) }\end{array}$ & & $\begin{array}{c}117 \\
(1.0)\end{array}$ & $\begin{array}{l}2967 \\
\text { (0.6) }\end{array}$ & \\
\hline No & $\begin{array}{l}12619 \\
(98.9)\end{array}$ & $\begin{array}{c}514424 \\
(99.4)\end{array}$ & & $\begin{array}{r}23612 \\
(99 \cdot 3)\end{array}$ & $\begin{array}{c}503431 \\
(99.4)\end{array}$ & & $\begin{array}{l}11181 \\
(99.0)\end{array}$ & $\begin{array}{c}515862 \\
(99.4)\end{array}$ & \\
\hline Hypospadias & & & $<0.001$ & & & $<0.001$ & & & $<0.001$ \\
\hline Yes & $\begin{array}{c}52 \\
(0.4)\end{array}$ & $\begin{array}{c}829 \\
(0.2)\end{array}$ & & $\begin{array}{c}69 \\
(0.3)\end{array}$ & $\begin{array}{c}812 \\
(0.2)\end{array}$ & & $\begin{array}{c}52 \\
(0.5)\end{array}$ & $\begin{array}{l}829 \\
(0.2)\end{array}$ & \\
\hline No & $\begin{array}{l}12709 \\
(99.6)\end{array}$ & $\begin{array}{c}516537 \\
(99.8)\end{array}$ & & $\begin{array}{c}23720 \\
(99.7)\end{array}$ & $\begin{array}{c}505526 \\
(99.8)\end{array}$ & & $\begin{array}{l}11246 \\
(99.5)\end{array}$ & $\begin{array}{c}518 \text { ooo } \\
(99.8)\end{array}$ & \\
\hline $\begin{array}{l}\text { Genital } \\
\text { cancers }\end{array}$ & & & 0.698 & & & 0.220 & & & 0.606 \\
\hline Yes & $\begin{array}{l}26 \\
(0.2)\end{array}$ & $\begin{array}{c}976 \\
(0.2)\end{array}$ & & $\begin{array}{c}53 \\
(0.2)\end{array}$ & $\begin{array}{c}949 \\
(0.2)\end{array}$ & & $\begin{array}{c}19 \\
(0.2)\end{array}$ & $\begin{array}{c}983 \\
(0.2)\end{array}$ & \\
\hline No & $\begin{array}{l}12735 \\
(99.8)\end{array}$ & $\begin{array}{c}516390 \\
(99.8)\end{array}$ & & $\begin{array}{l}23736 \\
(99.8)\end{array}$ & $\begin{array}{c}505389 \\
(99.8)\end{array}$ & & $\begin{array}{l}11279 \\
(99.8)\end{array}$ & $\begin{array}{c}517846 \\
(99.8)\end{array}$ & \\
\hline
\end{tabular}

Men in the older cohort who were born SGA had more often been diagnosed with infertility than men born AGA (5.7\% vs. $5.3 \%, \mathrm{p}=0.012$ ). When being patients at IVF-clinics, they also needed sperm donation (3.8\% vs. 2.5\%, $\mathrm{p}=0.031)$ and were partners in couples needing oocyte donation (3.9\% vs.2.5\%, $\mathrm{p}=0.019$ ) more often than men born AGA. When ART treatments were performed with the couple's own oocytes and spermatozoa, ICSI had to be performed for $49.2 \%$ of the men born SGA in the older cohort compared with $42.7 \%$ of the men born AGA ( $p=0.005)$. These differences were not shown for men born preterm or with LBW.

No differences were found in the chance of conceiving after ART, number of ART treatments needed to achieve the first delivery of a child or time from first ART treatment to the first child in relation to birth characteristics. 


\section{Main findings in study IV}

Sperm DNA fragmentation parameters yielded by the SCD assay (Halosperm ${ }^{\circledR} \mathrm{G} 2$ ) and the SCSA assay (DFI) were highly correlated ( $\mathrm{R}=0.82$, $\mathrm{p}<0.05$ ) in semen donors and in patients. A Bland-Altman plot analysis could confirm these results. The coefficient of variation between the replicate analyses was $3.6 \%$ for the SCSA and $4.7 \%$ for Halosperm ${ }^{\circledR} \mathrm{G} 2$.

Men with unexplained infertility had a higher proportion of spermatozoa showing DNA fragmentation with either method compared with fertile donors. The patients had a mean SDF of 40.1\% \pm 9.0 (95\% CI 37.4-42.8, range 24.659.6) and DFI $40.2 \% \pm 19.3$ (95\% CI 34.4-46.0, range 2.3-80) compared with fertile donors who had a mean SDF of $20.9 \% \pm 9.4$ (95\% CI 16.0-25.8, range 6.8-41.0) and DFI 17.1\% \pm 7.8 (95\% CI 13.0-21.2, range 6.9-31.2), $\mathrm{p}<0.05$. Values from the two methods did not differ statistically significant within the groups.

Spermatozoa from the infertile men were also analysed after density gradient centrifugation. The proportion of spermatozoa with DNA fragmentation after sperm selection was significantly lower $(\mathrm{p}<0.05)$ with SDF $10.0 \% \pm 5.9$ (range 2.3-30.9) and DFI $11.9 \pm 11.2$ (range 0.6-53.5).

\section{Main findings in study $\mathrm{V}$}

The reference group consisted of 236 men with known size at birth and for whom the SDF could be analysed. For $90(38.1 \%)$ of the men, the infertility diagnose was female factor, $30(12.7 \%)$ were diagnosed with male factor, 26 (11.0\%) were diagnosed with combined factor, and for 91 (38.6\%) men the infertility was unexplained.

In spermatozoa analysed after density gradient centrifugation, SDF was inversely correlated to the total amount of spermatozoa in men born AGA. For a total sperm count one million higher, the SDF was on average $0.1 \%$ lower (95\% CI 0.03-0.2, $\mathrm{p}=0.01$ ). No association between SDF and age could be found. 
Only six of the men in the study were born SGA, and SDF was possible to analyse for four of them. No statistically significant differences could therefore be detected, but as shown in table, the median SDF for men born SGA was higher than for men born AGA. The Halosperm ${ }^{\circledR} \mathrm{G} 2$ analysis was performed after gradient density centrifugation. The highest values of SDF were 36.0 and 43.7 , suggesting that even after sperm selection some men have a proportion of spermatozoa with DNA fragmentation large enough to negatively affect pregnancy outcomes.

Table 10. Age, total sperm count and sperm DNA fragmentation in men born SGA or AGA

\begin{tabular}{|c|c|c|c|}
\hline \multicolumn{4}{|c|}{ SGA } \\
\hline & $\begin{array}{c}\text { Yes } \\
\text { median (range) }\end{array}$ & $\begin{array}{c}\text { No } \\
\text { median (range) }\end{array}$ & $\mathrm{p}$-value \\
\hline Age (range) & $33(31-44)$ & $33(22-44)$ & 0.79 \\
\hline $\begin{array}{l}\text { Total sperm count } \\
\text { (range) }\end{array}$ & $32.0(1.1-76.0)$ & $40.0(0.02-350)$ & 0.32 \\
\hline SDF (range) & $16.6(2.9-36.0)$ & $6.4(0.4-43.7)$ & 0.20 \\
\hline
\end{tabular}




\section{Discussion}

\section{Interpretation of the findings}

Most men born 1973-1983 who had become fathers after ART up until 2007 were born at term, with normal birth weight and normal size of gestational age. Still, study I demonstrated that a larger proportion of them were born with nonoptimal birth characteristics compared with men who did not need ART to conceive. The results were statistically significant for LBW but not quite for men born preterm.

Not even the oldest men had turned 40 in 2007. This might explain why the cohort of fathers after ART only consisted of about 1,200 men. A longer followup time until more men had reached the end of their reproductive period would probably have increased the index cases (even if men can be fertile at high age, most men become fathers before 45 years of age as the mean age at the birth of their third child for fathers was 37-38 years between 2000-2012(103)).

The likelihood of being born SGA was not shown to be significantly increased for fathers after ART, but when ICSI had to be performed instead of conventional IVF, the likelihood of being born SGA was doubled. Less than half of the men born AGA needed ICSI (45\%) compared with almost two thirds (63\%) of the men born SGA. Presuming that the use of ICSI can be regarded as a token of lower sperm quality, this implied that men born SGA did have a higher risk of male factor infertility, even if this study could not confirm an increased likelihood of being born SGA when fathering by ART.

The use of a smaller control group could explain why the likelihood of being born SGA was not significantly increased. Only men where the ART had been successful were included. Maybe men born SGA were not overrepresented in this group since they had a lower chance of pregnancy after ART?

In study II one of the aims was, because of the questions raised in the first study, to evaluate the outcomes after ART in relation to birth characteristics. Both a large reference group and a smaller control group were also chosen, trying to address the problem with sample size as truthfully as possible. It turned out that birth characteristics did not affect the rates of either pregnancies or live births after ART, suggesting that even though men born with non-optimal birth 
characteristics more often have difficulties to become fathers by natural conception, the ART treatments offered have an equally good chance of succeeding as it has for men born AGA with normal birth weight.

Men born SGA did have an increased risk of male factor infertility, as hypothesised in paper I. BMI changed the OR of being born SGA and must be considered a confounding factor. Obesity was not more common in men born SGA than in the total population. Weight and metabolic consequences in adulthood for individuals born SGA can be related to the catch-up growth and not only to the intra-uterine growth restriction. Rapid gain in weight relative to length in the first three months of life have been associated with reduced insulin sensitivity, increased abdominal fat, and a less favourable lipid profile (24). These are all conditions linked to the metabolic syndrome and may deteriorate reproductive function in men in the absence of obesity (104-106). Almost all men in study II were healthy and without medication as most men in this age group, but undetected insulin resistance or other early signs of the metabolic syndrome could not be ruled out.

Smoking is a probable risk factor of male infertility (107), and it might therefore seem unexpected that a smaller proportion of the infertile men were habitual smokers compared with the total population. Snuff use was also less common for men with male factor infertility, but men with other factors of infertility used snuff to the same extent as the total population of men. One explanation of these findings is that men trying to achieve a pregnancy quit smoking, either because they have been informed of a potential sperm damaging effect or because they want to protect their female partner from passive smoking (as the negative effect of smoke on pregnancy outcome must be considered common knowledge). Snuff consumption has previously been associated with poorer semen quality but the effects on semen parameters has not been sufficiently investigated (108). It is possible that men after being informed of semen parameters below normal decide to quit using snuff. There is no evidence or scientific rationale that snuff use should improve semen parameters.

Paper III was based on a register study where the reproductive rate for men born 1973-1983 was estimated when the oldest men were 44 years old and could be compared both with their own reproductive rate 12 years earlier in 2006, and with the rate of a cohort born 1984-1993 who were about the same age as the older cohort was in 2006.

The likelihood of reproducing had not improved for men born SGA or with LBW in the older cohort when comparing rates from 2006 and 2018. In 2006, it was not clear whether men born SGA or LBW only postponed their parenthood, but 
with the longer follow up it became evident that they did become fathers to a lesser extent.

Men born SGA and with LBW in the younger cohort also had lower reproductive rates compared with men born with normal birth characteristics, but the rates were higher than those for the older cohort.

The proportion of men born LBW was rather similar between the age cohorts but men in the younger cohort were not as often born SGA. It was not possible to evaluate why the proportion of men born SGA was smaller in the younger cohort. However, maternal pre-pregnancy weight has increased since the 1970's and might be one explanation since low maternal weight increases the risk of the offspring being born SGA (109). The maternal health care has improved over the years which may decrease the number of children with IUGR. No adjustments were made for socioeconomic factors in the study, but the education level and income have increased, which should reduce the risk of IUGR/SGA. Prenatal testing including genetic analyses were more widely offered in the 90's than in the 70's which may have led to more terminations of pregnancies where genetic syndromes causing severe disabilities were discovered.

Prematurity did not seem to affect the likelihood of becoming a father, especially not for the younger cohort as those who had become fathers were more often born preterm than men who were childless. PTB was the only non-optimal birth characteristic where the proportion of affected men was higher in the younger cohort.

Being single, born with undescended testicle(s), and born with hypospadias were more common for men with all non-optimal birth characteristics and decreased most certainly the likelihood of reproducing. Hypospadias and undescended testicle(s) are symptoms of testicular dysgenesis syndrome and are also associated with low semen quality $(44,46)$. A Swedish cohort study recently demonstrated that men born with hypospadias had lower birth rates, increased use of ART and higher risk of being diagnosed with infertility (110). Still, only men born SGA were more often diagnosed with infertility, not men born preterm or with LBW. These findings suggest, as did findings in paper I and II, that men born SGA have an increased risk of sperm dysfunction and are in line with previous studies (31). When analysing the results from Q-IVF which included ART treatments that did not result in childbirth, the association could be further established: men born SGA needed sperm donation more often than men born AGA. Together with the finding that men born SGA more often needed ICSI instead of conventional IVF, the results indicate an increased risk of sperm 
dysfunction for men born SGA with as much certainty as possible considering the retrospective design.

Treatment cycles with donated oocytes were also more common for men born SGA compared with AGA men. Are men born SGA more prone to find partners with low ovarian reserve? No information was available on female factors such as FSH units needed per retrieved oocyte, number of retrieved oocytes in total, antral follicle count, or levels of anti-Müllerian Hormone (AMH). No associations between likelihood of having a partner with low ovarian reserve when born SGA could therefore be evaluated. Another explanation to the increased need of oocyte donation could be sperm dysfunction. Treatment cycles with no embryos of good quality to transfer, may lead to the use of donated oocytes even if the low quality was caused by sperm factors, for instance SDF. Mature oocytes of good quality have the capacity to repair moderate sperm DNA damage. However, if the oocytes cannot compensate for a deteriorated sperm function, a lower chance of blastocyst formation and implantation may lead to a decision of donation cycles. As SDF can be high even when other sperm parameters are close to normal, an impaired sperm function caused by DNA fragmentation may not be discovered and oocyte donation instead of sperm donation may be chosen.

We hypothesised that the proportion of spermatozoa with SDF was higher in men born SGA. In order to establish a method more easily performed in a clinical setting, we compared the results of Halosperm ${ }^{\circledR} \mathrm{G} 2$ with the results of SCSA, today probably the most common method to measure sperm DNA fragmentation (111). The sperm DNA fragmentation estimations from the two different methods were highly correlated and as a Bland Altman analysis also showed a good agreement between the methods, Halosperm ${ }^{\circledR} \mathrm{G} 2$ could be considered a reliable tool for clinical use in our setting.

When performing SCSA, not only do the analysis reveal the proportion of spermatozoa with DNA fragmentation but also the level of high DNA stainability (HDS). HDS is supposed to be a measurement of immature spermatozoa. Methods such as Halosperm ${ }^{\circledR} \mathrm{G} 2$ do not measure HDS or any other parameters reflecting the degree of condensation of the sperm chromatin. High levels of HDS ( $\geq 15 \%$ ) have been associated with a lower fertilisation rate when performing conventional IVF, suggesting that ICSI should be performed for these men (112). On the other hand, HDS $\geq 15 \%$ has also been associated with an increased risk of early miscarriage, but only in pregnancies after ICSI and not after IVF (113). If the increased fertilisation rate when choosing ICSI because of 
high HDS levels only increases the miscarriage rates or if it also increases the baby take home rate has not yet been clarified. Until this matter has been addressed, the information on DNA integrity accessed by Halosperm ${ }^{\circledR} \mathrm{G} 2$ might be sufficient.

SDF was found to be higher in men with unexplained infertility compared with fertile donors. Our results are in line with previous studies $(51,67,68)$. SDF levels were rather high in our study, probably caused by the time interval from ejaculation to analysis.

The SDF in spermatozoa after selection by density gradient centrifugation have shown contradictory results in previous studies $(114,115)$. In our study of patients undergoing IVF where comparisons were planned between the levels of SDF in men born SGA and AGA (study V), we knew that SDF was to be analysed on spermatozoa after density gradient centrifugation. Most SDF reference values are valid for spermatozoa before any selection has been performed and are therefore difficult to apply on selected spermatozoa. We compared the SDF of the spermatozoa from the infertile men both before and after density gradient centrifugation in study IV and found significantly lower SDF after selection. With these results, the SDF levels in spermatozoa after density gradient centrifugation when comparing men born SGA and AGA, were not expected to overestimate the DNA fragmentation but rather to have a risk of underestimation.

Contrary to previous results $(66,116,117)$, we could not find any associations between SDF and age. The oldest men in our study were 46 years, and median age was 33 years in both men born SGA and AGA. Even if SDF increases with age, there are men in younger ages with high SDF (66). These probable outliers, together with the low median age in our study, may explain the lack of association between SDF and age.

\section{Methodological considerations}

Register data were used in four of the studies included in this thesis. The cohort and case control studies based on large population registers evaluate the association between an exposure and different outcomes, but conclusions on causality cannot be drawn. On the other hand, the large populations used make it possible to study rare conditions, as it allows for greater number of cases with the chosen exposures and outcomes compared with using clinical data. Another advantage with studies based on registers is that the data already exist, which 
makes data collection faster. The selection bias caused by non-response and loss to follow-up in surveys and other researcher-collected data is very limited in register-based studies, where the participation is close to complete (118).

The exposure in all studies where register data were used was size for gestational age (birth weight and gestational age at birth were also considered exposures in three of the studies). When information on birth data on children are reported by their parents, the risk of recall bias is large. This is not a problem when using registers as the collection of data has been done independently and before the studies were performed.

Data collection independent of a study reduces the recollection bias but can pose other problems as the researcher has no influence on the variables. The National Patient Register has been reviewed and the validity is high for many diagnoses (89). Still, the coding of diseases may vary over time or between institutions. In study III, we have tried to overcome this problem by using variables from different registers. Infertility was of course presumed when an individual had the corresponding ICD code in NPR, but also when the individual had been a patient at an IVF-clinic and data could be retrieved from Q-IVF. Q-IVF is a quality register where an individual can choose not to participate but as very few persons decline, it is considered to be a valid register covering almost all ART treatments performed in Sweden.

Infertility can be caused by many factors but can only be diagnosed if a person tries to conceive. This explains the results in study III, where men who had fathered a child were more often diagnosed with infertility than men who had not become fathers. Reproductive disturbances including azoospermia are not noticed unless looked for. It is therefore possible for a sterile man with no production of spermatozoa to avoid a diagnose of infertility, if he never tries to become a parent (an analysis of semen parameters is very rarely performed without a wish to conceive). An infertile man can also choose not to go through the medical examination or can be denied at least a publicly funded evaluation as specific criteria must be fulfilled to be entitled it. Infertility and its causes may therefore be underdiagnosed. The likelihood of becoming a father is another way of describing reproduction in men born with non-optimal birth characteristics, but it is not equivalent to infertility.

When estimating the impact of birth characteristics on infertility and reproduction, we have focused more on SGA than on the other variables. Information on the true variable we are looking for, intra-uterine growth retardation, is not possible to extract from the registers. Children born SGA can be genetically small and not growth restricted in any way. The causes of SGA are 
also difficult to identify in register data. We have chosen not to take reports on maternal smoking into account as the registration on smoking habits in the MBR was not reliable, at least not during the first years. Nowadays the reported smoking habits correlate rather well with the cotinine levels in maternal and cord blood at delivery and in future studies this may help to evaluate risks of infertility in the offspring (119).

Further, different definitions of SGA exist. The definition in our studies and throughout this thesis is that SGA is a birth weight <-2SDs of the mean for the infant's gestational age, recommended by, among others, the International SGA Advisory Board Panel $(19,20)$. Fewer children are born SGA with this definition than when using the $10^{\text {th }}$ percentile definition used by WHO (17). With a more conservative definition of the diagnose, the associations between size for gestational age and the different outcomes become more evident and hopefully also more correct.

Estimations of gestational age from 1973 until the mid-80's, when ultrasonograms were introduced, were based on the time from last menstrual period. The intrauterine growth curves used to calculate SGA were provided in 1996 and, as the mean birth weight has increased over time, may underestimate SGA in those born prior to 1996 (21). Errors when entering data on birth weight and gestational age can also be a problem when collecting information from registers.

Diagnostic difficulties are not only a problem when data come from registers. The accuracy when diagnosing the cause of infertility is dependent on the quality of the evaluation as well as the diagnostic thresholds. For example: is endometriosis the cause of infertility in a couple where the woman previously has been diagnosed with endometriosis based on histological analysis of a peritoneal biopsy but has no macroscopical signs of disease and no other causes of infertility have been found, such as occluded Fallopian tubes or anovulation? Male factor infertility is based on the results from semen sample analyses. At least two samples with parameters below the normal values are needed to correctly diagnose a man with male factor infertility. The diagnosis is thus dependent on the number of semen samples analysed, and this may lead to misclassification bias. Study II was based not only on register data but also on information from medical records at our own clinic, and all diagnosed infertility factors could be - and were - re-evaluated. The risk of misclassification of the infertility factors thereby decreased but it could not be totally avoided.

The index men in study II, IV and V were patients or donors at RMC, University Hospital, Linköping. Individuals included lived all over the South-east region of Sweden which has both urban and rural areas and mirrors the total population rather well. Results from the study were considered generalisable to a national 
context as the ART treatments were publicly funded and did not include a selection bias.

As mentioned earlier, one of the advantages with register studies is the large study population. This may also impose a problem, as even very small differences probably without clinical significance will become statistically significant. To avoid that problem, we decided to use four age-matched controls for each index person in study I. In study II, we decided to use both a large reference group consisting of all men born during the same time interval as the index persons and a control group of two age-matched men for each index man. The purpose of two control groups of different sizes was to more truly describe both what kind of impact birth characteristics may have on infertility and how important that impact was. In short, a large sample size will make small differences significant, and using few controls will only reveal strong associations but may risk "hiding" true but smaller differences.

Study V suffers from another type of sample size problem. When planning the study, an expected prevalence of SGA of 4-5\% led to the estimation that a sample size of about 500 men would be enough to detect differences in SDF between men born SGA and AGA. Unfortunately, the prevalence of SGA appeared to be much lower than expected, only about $1 \%$. The sample size was therefore too small to draw any conclusions. The process to retrieve data on size for gestational age from the National Board of Health Care had been timeconsuming and had taken over one year. An additional request of data from the MBR on an extended sample could therefore not easily be pursued.

The comparison between two different methods to analyse SDF in study IV was performed to ensure that the results in our lab from the Halosperm method did not differ compared with the results from SCSA. The Halosperm method is clinically advantageous, being more easily introduced in a clinical setting as no new equipment nor specialised technical know-how are needed to carry out the analyses. The inter-rater reliability of the analyses was tested as two different persons performed the estimations. The results from the two methods correlated highly. 


\section{Methodological difficulties along the path as $\mathrm{PhD}$ student}

When deciding to study male infertility in relation to birth characteristics as a $\mathrm{PhD}$ project, we initially wanted to include several different aspects of the concept of male infertility. Other factors than just the semen parameters conventionally analysed may affect a man's possibility of becoming a father, especially since the reduced likelihood of reproducing associated with nonoptimal birth characteristics cannot be explained only by a correlation between semen parameters and birth data. We decided to analyse sperm DNA fragmentation, hypothesising that SDF was related to size for gestational age. Unfortunately, the results could only support and not prove the hypothesis due to low statistical power.

Pregnancy is a condition that challenges the immune system in the pregnant woman. A balance between pro- and anti-inflammatory events must prevail to allow for an implantation and further normal growth of an embryo. It is probable that immunological factors such as cytokines and chemokines present in the seminal fluid can influence the female immunological response to the developing early embryo and both promote and inhibit the implantation process $(120,121)$. We therefore measured selected immunological factors in different parts of the ejaculate and investigated differences between men with different types of infertility. The results were difficult to interpret and were therefore not published.

Factors present in the seminal plasma may influence the implantation of an embryo, but they are not necessary to establish a pregnancy. Pregnancies after ART are common, and in the ART process only the spermatozoa are extracted, and the seminal plasma is discarded. To find out if pregnancy rates after ART can be improved with factors present in seminal fluid, a clinical intervention study was set up. The study named SENAVA (SEminal plasma or NACl VAginally) was registered at clinicaltrials.gov. Couples going through ART could after informed consent be included and randomized for application of either seminal plasma from the male partner or $\mathrm{NaCl}$ (placebo) in the vaginal fornix directly after ovum pick-up. The primary outcome is pregnancy after ART. After sample size calculation with an expected improvement of pregnancy rates of $10 \%, 800$ couples have been included. The inclusion is now completed (September 2021) and as soon as all outcome parameters have been collected, statistical analyses will be performed. Couples participating in the study also consented to extended analyses of spermatozoa not used in the treatment. SDF analyses reported in paper IV and V were performed on spermatozoa from men participating in the SENAVA study. 


\section{Conclusions}

Men becoming fathers by ART had an increased likelihood of being born with LBW compared with men becoming fathers without ART.

Men becoming fathers by ICSI had an increased likelihood of being born SGA compared with men becoming fathers by conventional IVF and compared with men becoming fathers without ART.

Men with male factor infertility were more often born SGA, preterm or with LBW than men of the same age in general. They also had an increased likelihood of being born SGA and with LBW compared with men with other infertility factors but only significantly increased compared with men with unexplained infertility.

The low likelihood of becoming a parent for men born SGA or with LBW had not improved after further 12 years of follow-up.

The treatment outcomes after ART were not significantly different between men in relation to their infertility factor, nor to their birth characteristics.

Men born SGA between 1973 and 1983 had more often been diagnosed with infertility than men born AGA. When they were patients at an IVF-clinic, men born SGA more often needed sperm or oocyte donation, and ICSI was more often performed compared with men born AGA.

Sperm DNA fragmentation results from Halosperm ${ }^{\circledR} \mathrm{G} 2$ and SCSA highly correlated in samples from infertile men and from healthy donors.

Men with unexplained infertility had a larger proportion of spermatozoa with DNA fragmentation than fertile donors. The proportion of spermatozoa with DNA fragmentation became smaller after density gradient centrifugation.

Men born SGA might have a larger proportion of spermatozoa with DNA fragmentation, but larger studies are needed. 


\section{Clinical implications and future perspectives}

Men born with non-optimal birth characteristics, especially men born SGA, have a lower probability to become fathers and some of the reasons are discussed in this thesis. Although being born SGA does not seem to directly affect the sperm number, concentration, or mobility, the prevalence of infertility is higher in men born SGA and they also more often need ICSI or sperm donation to become fathers. We believe that sperm DNA fragmentation might be an explanation. Because of the unexpected low number of men born SGA, no conclusions could be made regarding associations between size for gestational age and SDF in our study. The median SDF was higher for men born SGA than for men born AGA, strengthening our hypothesis but further research is of course necessary to confirm such an association.

Studies of infertile men where DNA fragmentation already has been analysed could be performed by accessing data from MBR, aiming at finding associations between birth characteristics and SDF.

The incidence of SGA is decreasing, as shown in paper III when comparing an older cohort born 1973-1983 with a younger, born 1984-1993. Perhaps the increased surveillance of pregnancies with improved maternal health care and a more advanced neonatal care also have led to fewer long-term effects of SGA on future reproductive capacity. Rather few of the younger men in this study had been patients at an IVF-clinic. For those who had been patients, no differences in use of ICSI or donation cycles could be seen between men born SGA compared with men born AGA. One explanation could be that the younger men had not yet tried to become a father, but it cannot be ruled out that the impact of SGA on reproduction is decreasing. Young men also tend to have female partners of young age. If men born SGA have a higher level of sperm DNA fragmentation, the impact on their reproduction may become more apparent with increasing age of both themselves and their partners.

Men born with non-optimal birth characteristics are more often single, but that does not totally explain the lower likelihood of becoming a father. Prospective studies on men born SGA would clarify to what extent the lower reproductive rate can be explained by fertility issues such as lower fertilisation potential in sperm, SDF, and azoospermia. Prospective studies could also include evaluation of the individual wish to become a parent. A long-term follow up of men born SGA should include not only questionnaires and blood samples but also semen samples. 


\section{Populärvetenskaplig sammanfattning}

\section{Infertilitet är vanligare hos män som föddes underviktiga}

Oförmågan att få barn trots mer än ett års försök, infertilitet, är vanligt. Ungefär $15 \%$ av alla par behöver medicinsk hjälp för att få barn, och den vanligaste behandlingen idag är provrörsbefruktning, IVF. En barnlöshetsutredning av mannen och kvinnan i paret leder ofta till att faktorer hos kvinnan (ca 25-35\%), mannen (20-30\%) eller båda (25-40\%) kan förklara infertiliteten. Hos ungefär $20 \%$ hittar man ingen orsak och barnlösheten benämns då oförklarad.

Män utreds alltid med spermaprov. När två eller flera spermaprov visar lägre nivåer än normalt på spermiernas antal, rörlighet eller andelen spermier med normalt utseende så finns en manlig faktor. Om det finns få spermier i spermaprovet eller om spermierna har en dålig rörlighet måste man vid provrörsbefruktning hjälpa spermien att ta sig in i ägget. Denna teknik kallas ICSI (intra-cytoplasmic sperm injection).

Det finns många orsaker till att män har svårt att bli pappor. I tidigare studier har man sett att män som var födda med en födelsevikt under den förväntade (små för tiden, SGA), med låg födelsevikt (under 2500 gram) eller för tidigt (prematurt, födda före 37:e graviditetsveckan) hade en lägre sannolikhet att bli fäder än män som var födda med normal vikt i fullgången tid.

Syftet med denna avhandling var att undersöka om denna lägre sannolikhet att bli pappa kunde bero på att männen oftare hade en manlig faktor som förklaring till barnlösheten, det vill säga om det oftare behövdes ICSI eller spermiedonation för att hjälpa dessa män att bli pappor. Syftet var även att ta reda på om deras chans att få barn med hjälp av assisterad befruktning var försämrad. Vi ville också undersöka om skador på spermiens arvsmassa (DNA) var vanligare hos män födda underviktiga än hos män födda normalviktiga.

Den första studien undersökte svenska män som blivit fäder med hjälp av assisterad befruktning. Dessa män visade sig oftare vara födda med låg födelsevikt än män som blivit fäder på naturlig väg. Män som blivit fäder med hjälp av ICSI, en metod som alltså används vid dåligt spermaprov, var oftare födda underviktiga/små för tiden än både män som blivit fäder naturligt och män som blivit fäder med vanlig provrörsbefruktning. Man behövde utföra ICSI för $63 \%$ av männen födda små för tiden men bara för $45 \%$ av männen som var födda normalviktiga. 
I studie nummer II undersöktes män födda 1973-1986 som varit patienter på Reproduktionsmedicinskt centrum i Linköping på grund av barnlöshet.

Män som hade en manlig faktor som förklaring till barnlösheten var oftare födda små för tiden eller med låg födelsevikt jämfört med män som inte fått barn på grund av faktorer hos kvinnan eller där barnlösheten var oförklarad. Det var också en högre andel av männen med manlig infertilitetsfaktor som var födda för tidigt, med låg födelsevikt eller små för tiden jämfört med alla män födda under samma tidsperiod i hela Sverige. Männens födelsevikt och storlek vid födseln hade ingen betydelse för om behandling med assisterad befruktning ledde till en graviditet eller ej.

Alla män födda i Sverige 1973-1994 undersöktes med hjälp av data från olika register i den tredje studien. Männen delades upp i två åldersgrupper: de födda 1973-1983 och de födda 1984-1993. Män som var födda små för tiden eller med låg födelsevikt hade inte blivit fäder lika ofta som män födda normalstora. I den äldre gruppen gällde detta även män som var födda för tidigt. Det var vanligare att vara singel (aldrig varit gift eller registrerad sambo) och att vara född med testikelretention för männen födda små för tiden, för tidigt eller med låg födelsevikt. I den äldre åldersgruppen var det också vanligare för män födda små för tiden som varit patienter på en IVF-klinik att behöva ICSI eller spermiedonation än för män födda normalstora. Inte heller i denna studie påverkade födelsevikt eller storlek vid födseln resultaten vid assisterad befruktning.

Den fjärde studien jämförde två metoder för att analysera skador i DNA hos spermier. Metoden Halosperm ${ }^{\circledR} \mathrm{G} 2$, som är enklare att genomföra på laboratoriet och som inte kräver inköp av dyr utrustning, visade sig vara lika bra som referensmetoden, SCSA. När man ska genomföra en provrörsbefruktning vill man använda sig av de spermier som har högst rörlighet. Spermaprovet genomgår därför en procedur för att sortera bort orörliga och döda spermier. Studien visade att andelen spermier med DNA-skador var lägre hos de spermier som sorterats fram för att användas till provrörsbefruktningen.

Den avslutande studien i avhandlingen undersökte om det fanns skillnad i andel spermier med DNA-skador mellan män födda små för tiden och män som föddes normalstora. Runt 550 män som genomgick behandling med assisterad befruktning vid Reproduktionsmedicinskt centrum i Linköping deltog i studien men endast sex män av dessa visade sig vara födda små för tiden (ett antal som var betydligt lägre än förväntat). Det gick därför inte att dra några statistiskt säkra slutsatser av studien. Dock sågs en tendens till skillnad eftersom medianvärdet på andelen spermier med DNA-skador var 16,6\% för män födda 
små för tiden, men 6,4\% för män födda normalstora. En större studie behövs för att kunna bekräfta hypotesen.

Sammanfattningsvis pekar resultaten i denna avhandling på att män som föds små för tiden har en ökad risk för barnlöshet och en ökad risk för att behöva ICSI och spermiedonation för att bli fäder. När män födda små för tiden genomgår behandling med assisterad befruktning är dock chansen att lyckas få barn lika stor som för andra män. 


\section{Acknowledgements}

It is a truth universally acknowledged, that a $\mathrm{PhD}$ student must be in want of excellent supervisors. And I am truly grateful to all of mine:

Professor emeritus Mats Hammar, my main supervisor, for your encouragement during all these years. You are one of the kindest persons I have ever met, and you have a way of making me feel very skilful and clever even when I ask the same question for the millionth time.

Associate Professor Elizabeth Nedstrand, my co-supervisor but also my boss, colleague, and friend, for caring and supporting me in every way. You are always ready to help sorting out big or small problems. I really appreciate your honesty and how you have helped me grow some (more) backbone.

Professor emeritus Heriberto Rodriguez Martinez, my co-supervisor, for your patience when trying to help me understand the wonders of spermatozoa, chromatin damage, and seminal fluid. I think I have learned something new in every conversation I have ever had with you.

Professor Gunilla Sydsjö, my co-supervisor, for so generously sharing your knowledge on both science and on the care of our patients. I have learnt so much from working with you. You also know how to smoothen the bumps in the road to a PhD and you never hesitate to celebrate even the smallest success.

Many others have supported me during this $\mathrm{PhD}$ project and in particular, I would like to thank:

Marie Bladh, PhD, for introducing me to Pearson, Bonferroni, and Cox, and for helping me stop fearing them. I always enjoy our nice chats on everything from the really important things in life to the simpler ones (like p-values). May the odds be ever in your favour!

Manuel Alvarez Rodriguez, Associate Professor, for excellent laboratory skills and collaboration. You have made me feel so welcome when I have left the clinic and boldly gone where not many gynaecologists have gone before.

All staff at RMC, Linköping University Hospital, for recruiting and including almost every eligible patient to our studies. It is great being part of such a 
competent team. Special thanks to Birgitta Fält and Stefan Zalavary for making it fun and rewarding to co-lead the unit.

Marie Rubér, PhD, Isabelle Pehrson, PhD student, and Laura GarciaCalvo, PhD, for invaluable help with all semen samples collected for study IV and $\mathrm{V}$ and for making sure that study IV could be completed.

Associate Professor Firas Aljabery, Professor emeritus Göran Berg, Dr Charlotte Ginstman, Associate Professor Wei Li, Dr Agota Malmborg, Dr Anna Ramö Isgren, and Dr Stefan Zalavary, for reviewing my manuscripts and thesis and contributing with valuable opinions.

Associate Professor Elizabeth Nedstrand, head of the Department of Obstetrics and Gynaecology in Linköping, Dr Sofia Pihl, Associate Professor Eva Uustal, and Dr Anna Karlsson for giving me the time and schedule to complete this thesis.

All colleagues at the Department of Obstetrics and Gynaecology in Linköping, for making it so much fun to come to work every morning and for fruitful discussions on all aspects of reproduction.

All friends and hens. Some of you have been in my life since the high school years, others became my friends at the university, and there is a few of you who were grown-ups before I met you. Thank you for support in life and love and science. And for all the fun!

My mother Inger Johansson, who has taught me that happiness can be found even in the darkest of times. I am thankful to you, my sister Catarina Castman, my brother Björn Johansson Lindgren, their families, and my mother-in-law Gunilla Liffner, for your support and for never once doubting my abilities (at least not to my face).

Göran, my partner in just about everything, for always laughing at my jokes (even when they are not that funny). Life is a happy song when there is someone by your side to sing along - and where you go, I will go.

Frans and Sigrid, my children, for being the best gifts I have ever been given. Always. You learned at an early age that research is more about sitting in front of a computer than about exploring distant continents, but you don't have to travel far for magical things to happen. Remember: when in doubt, go to the library! 


\section{References}

1. Zegers-Hochschild F, Adamson GD, de Mouzon J, Ishihara O, Mansour R, Nygren K, et al. International Committee for Monitoring Assisted Reproductive Technology (ICMART) and the World Health Organization (WHO) revised glossary of ART terminology, 2009. Fertil Steril. 2009;92(5):1520-4.

2. Thoma M, Fledderjohann J, Cox C, Kantum Adageba R. Biological and Social Aspects of Human Infertility: A Global Perspective. Oxford University Press. 2021.

3. Zegers-Hochschild F, Adamson GD, Dyer S, Racowsky C, de Mouzon J, Sokol $\mathrm{R}$, et al. The International Glossary on Infertility and Fertility Care, 2017. Fertil Steril. 2017;108(3):393-406.

4. Cooper TG, Noonan E, von Eckardstein S, Auger J, Baker HW, Behre HM, et al. World Health Organization reference values for human semen characteristics. Hum Reprod Update. 2010;16(3):231-45.

5. Campbell MJ, Lotti F, Baldi E, Schlatt S, Festin MPR, Bjorndahl L, et al. Distribution of semen examination results 2020 - A follow up of data collated for the WHO semen analysis manual 2010. Andrology. 2021;9(3):817-22.

6. World Health Organization. WHO laboratory manual for the examination and processing of human semen.6th edition. 2021.

7. Levine H, Jorgensen N, Martino-Andrade A, Mendiola J, Weksler-Derri D, Mindlis I, et al. Temporal trends in sperm count: a systematic review and metaregression analysis. Hum Reprod Update. 2017;23(6):646-59.

8. Q-IVF K. Swedish National Quality Register of Assisted Reproduction https://www.medscinet.com/qivf/

9. The ESHRE Guideline Group On Ovarian Stimulation, Bosch E, Broer S, Griesinger G, Grynberg M, Humaidan P, et al. ESHRE guideline: ovarian stimulation for IVF/ICSI. Hum Reprod Open. 2020;2020(2):hoaa009.

10. ESHRE Guideline Group on Good Practice in IVF Labs, De los Santos MJ, Apter S, Coticchio G, Debrock S, Lundin K, et al. Revised guidelines for good practice in IVF laboratories (2015). Hum Reprod. 2016;31(4):685-6.

11. Palermo GD, Joris H, Devroey P, Van Steirteghem AC. Pregnancies after intracytoplasmic injection of single spermatozoon into an oocyte. Lancet. 1992;340:17-8.

12. Palermo GD, O'Neill CL, Chow S, Cheung S, Parrella A, Pereira N, et al. Intracytoplasmic sperm injection: state of the art in humans. Reproduction. 2017;154(6):F93-F110.

13. Barker D, Hales C, Fall C, Osmond C, Phipps K, Clark P. Type 2 (non-insulindependant) diabetes mellitus, hypertension and hyperlipidaemia (syndrome $\mathrm{X}$ ): relation to reduced fetal growth. Diabetologia. 1993;36(1):62-7.

14. Barker DJ. The developmental origins of insulin resistance. Horm Res. 2005;64 Suppl 3:2-7.

15. Barker DJ. The origins of the developmental origins theory. J Intern Med. 2007;261(5):412-7.

16. McMillen IC, Robinson JS. Developmental origins of the metabolic syndrome: prediction, plasticity, and programming. Physiol Rev. 2005;85(2):571-633.

17. World Health Organization. WHO Expert Committee on Physical Status: the Use and Interpretation of Anthropometry. 1993. 
18. Williams RL, Creasy RK, Cunningham GC, Hawes WE, Norris FD, Tashiro M. Fetal growth and perinatal viability in California. Obstet Gynecol. 1982;59(5):624-32.

19. Lee $\mathrm{P}$, Chernausek, SD, Hokken-Koelega,AC, Czernichow, P: for the International SGA Advisory Board. International Small for Gestational Age Advisory Board consensus development conference statement: management of short children born small for gestational age, April 24-October 1, 2001. Pediatrics. 2003;111(6):1253-61.

20. Clayton PE, Cianfarani S, Czernichow P, Johannsson G, Rapaport R, Rogol A. Management of the child born small for gestational age through to adulthood: a consensus statement of the International Societies of Pediatric Endocrinology and the Growth Hormone Research Society. J Clin Endocrinol Metab. 2007;92(3):804-10.

21. Marsal K, Persson PH, Larsen T, Lilja H, Selbing A, Sultan B. Intrauterine growth curves based on ultrasonically estimated foetal weights. Acta Paediatr. 1996;85(7):843-8.

22. Cobo T, Kacerovsky M, Jacobsson B. Risk factors for spontaneous preterm delivery. Int J Gynaecol Obstet. 2020;150(1):17-23.

23. Valero De Bernabe J, Soriano T, Albaladejo R, Juarranz M, Calle ME, Martinez D, et al. Risk factors for low birth weight: a review. Eur J Obstet Gynecol Reprod Biol. 2004;116(1):3-15.

24. Finken MJJ, van der Steen M, Smeets CCJ, Walenkamp MJE, de Bruin C, Hokken-Koelega ACS, et al. Children Born Small for Gestational Age: Differential Diagnosis, Molecular Genetic Evaluation, and Implications. Endocr Rev. 2018;39(6):851-94.

25. Saenger P, Czernichow P, Hughes I, Reiter EO. Small for gestational age: short stature and beyond. Endocr Rev. 2007;28(2):219-51.

26. Heinonen K RK, Pesonen AK, Andersson S, Kajantie E, Eriksson JG, Wolke D, Lano A. Behanvioural symptoms of attention deficit/hyperactivity disorder in preterm and term children born small and appropriate for gestational age: A longitudinal study. BMC Pediatrics. 2010;10(91).

27. Lahti M, Eriksson JG, Heinonen K, Kajantie E, Lahti J, Wahlbeck K, et al. Late preterm birth, post-term birth, and abnormal fetal growth as risk factors for severe mental disorders from early to late adulthood. Psychological Medicine. 2014;45(5):985-99.

28. Francois I, de Zegher F, Spiessens C, D'Hooghe T, Vanderschueren D. Low birth weight and subsequent male subfertility. Pediatr Res. 1997;42(6):899-901 .

29. Meas T, Deghmoun S, Levy-Marchal C, Bouyer J. Fertility is not altered in young adults born small for gestational age. Hum Reprod. 2010;25(9):2354-9.

30. deKeyser N, Josefsson A, Bladh M, Carstensen J, Finnstrom O, Sydsjo G. Premature birth and low birthweight are associated with a lower rate of reproduction in adulthood: a Swedish population-based registry study. Hum Reprod. 2012;27(4):1170-8.

31. Thorsted A, Lauridsen J, Hoyer B, Arendt LH, Bech B, Toft G, et al. Birth weight for gestational age and the risk of infertility: a Danish cohort study. Hum Reprod. 2020;35(1):195-202.

32. Cicognani A, Alessandroni R, Pasini A, Pirazzoli P, Cassio A, Barbieri E, et al. Low birth weight for gestational age and subsequent male gonadal function. $J$ Pediatr. 2002;141(3):376-9.

33. Vanbillemont G, Lapauw B, Bogaert V, De Naeyer H, De Bacquer D, Ruige J, et al. Birth weight in relation to sex steroid status and body composition in young healthy male siblings. J Clin Endocrinol Metab. 2010;95(4):1587-94. 
34. Jensen RB, Vielwerth S, Larsen T, Greisen G, Veldhuis J, Juul A. Pituitarygonadal function in adolescent males born appropriate or small for gestational age with or without intrauterine growth restriction. J Clin Endocrinol Metab. 2007;92(4):1353-7.

35. Boonstra VH, Weber RF, de Jong FH, Hokken-Koelega AC. Testis function in prepubertal boys and young men born small for gestational age. Horm Res. 2008;70(6):357-63.

36. Kerkhof GF, Leunissen RW, Willemsen RH, de Jong FH, Stijnen T, HokkenKoelega AC. Influence of preterm birth and birth size on gonadal function in young men. J Clin Endocrinol Metab. 2009;94(11):4243-50.

37. Boeri L, Ventimiglia E, Capogrosso P, Ippolito S, Pecoraro A, Paciotti M, et al. Low Birth Weight Is Associated with a Decreased Overall Adult Health Status and Reproductive Capability - Results of a Cross-Sectional Study in Primary Infertile Patients. PLoS One. 2016;11(11):e0166728.

38. Faure C, Dupont C, Chavatte-Palmer P, Gautier B, Levy R, Group AC. Are semen parameters related to birth weight? Fertil Steril. 2015;103(1):6-10.

39. Kahn LG, Widen EM, Janevic T, Straka N, Liu X, Cirillo PM, et al. The Relation of Birth Weight and Adiposity Across the Life Course to Semen Quality in Middle Age. Epidemiology. 2019;30 Suppl 2:S17-S27.

40. Ozturk O, Armstrong K, Bhattacharya S, Templeton A. Fetal antecedents of male factor sub-fertility: how important is birthweight? Hum Reprod. 2001;16(10):2238-41.

41. Ramlau-Hansen $\mathrm{CH}$, Hansen M, Jensen CR, Olsen J, Bonde JP, Thulstrup AM. Semen quality and reproductive hormones according to birthweight and body mass index in childhood and adult life: two decades of follow-up. Fertil Steril. 2010;94(2):610-8.

42. Whitcomb BW, Bloom MS, Kim S, Chen Z, Buck Louis GM. Male birthweight, semen quality and birth outcomes. Hum Reprod. 2017;32(3):505-13.

43. Main KM, Jensen RB, Asklund C, Hoi-Hansen CE, Skakkebaek NE. Low birth weight and male reproductive function. Horm Res. 2006;65 Suppl 3:116-22.

44. Skakkebaek NE, Rajpert-De Meyts E, Main KM. Testicular dysgenesis syndrome: a increasingly common developmental disorder with environmental aspects. Hum Reprod. 2001;16(5):972-8.

45. Skakkebaek NE, Rajpert-De Meyts E, Buck Louis GM, Toppari J, Andersson AM, Eisenberg ML, et al. Male Reproductive Disorders and Fertility Trends: Influences of Environment and Genetic Susceptibility. Physiol Rev. 2016;96(1):55-97.

46. Wohlfahrt-Veje C, Main KM, Skakkebaek NE. Testicular dysgenesis syndrome: foetal origin of adult reproductive problems. Clin Endocrinol (Oxf). 2009;71(4):459-65.

47. Hart RJ, Doherty DA, Keelan JA, McLachlan R, Skakkebaek NE, Norman RJ, et al. Early Life Events Predict Adult Testicular Function; Data Derived From the Western Australian (Raine) Birth Cohort. J Clin Endocrinol Metab. 2016;101(9):3333-44.

48. Agarwal A, Majzoub A, Esteves SC, Ko E, Ramasamy R, Zini A. Clinical utility of sperm DNA fragmentation testing: practice recommendations based on clinical scenarios. Transl Androl Urol. 2016;5(6):935-50.

49. Björndahl L, Kvist U. Structure of chromatin in spermatozoa. In: Baldi E, Muratori M, editors. Genetic Damage in Human Spermatozoa. 791. Advances in Experimental Medicine and Biology: Springer, New York, NY; 2014.

50. Agarwal A, Majzoub A, Baskaran S, Selvam MKP, Cho CL, Henkel R, et al. Sperm DNA Fragmentation: A New Guideline for Clinicians. World J Mens Health. 2020. 
51. Esteves SC, Zini A, Coward RM, Evenson DP, Gosalvez J, Lewis SEM, et al. Sperm DNA fragmentation testing: Summary evidence and clinical practice recommendations. Andrologia. 2020:e13874.

52. Ribas-Maynou J, Benet J. Single and Double Strand Sperm DNA Damage: Different Reproductive Effects on Male Fertility. Genes (Basel). 2019;10(2).

53. Ribas-Maynou J, Garcia-Peiro A, Fernandez-Encinas A, Abad C, Amengual MJ, Prada E, et al. Comprehensive analysis of sperm DNA fragmentation by five different assays: TUNEL assay, SCSA, SCD test and alkaline and neutral Comet assay. Andrology. 2013;1(5):715-22.

54. Ward WS. Eight tests for sperm DNA fragmentation and their roles in the clinic. Transl Androl Urol. 2017;6(Suppl 4):S468-S70.

55. Evenson DP. Sperm Chromatin Structure assay (SCSA): Evolution from origin to clinical utility. In: Zini A, Agarwal A, editors. A Clinician's Guide to Sperm DNA and Chromatin Damage: Springer Science, New York, NY; 2017.

56. Evenson DP, Jost LK, Corzett M, Balhorn R. Characteristics of human sperm chromation structure following an episode of influenza and high fever: a case study. J Androl. 2000;21(5):739-46.

57. Simon L, Castillo J, Oliva R, Lewis SE. Relationships between human sperm protamines, DNA damage and assisted reproduction outcomes. Reprod Biomed Online. 2011;23(6):724-34.

58. San Gabriel MC, Haddad N, Pedraza CE, Vingataramin L, LeSaint C, Bissonnette $F$, et al. The weak correlations between sperm dna fragmentation assays suggest that chromatin packaging is complex. Fertility and Sterility. 2017;108(3).

59. Mohammadi Z, Tavalaee M, Gharagozloo P, Drevet JR, Nasr-Esfahani MH. Could high DNA stainability (HDS) be a valuable indicator of sperm nuclear integrity? Basic Clin Androl. 2020;30:12.

60. Fernandez JL, Muriel L, Rivero MT, Goyanes V, Vazquez R, Alvarez JG. The Sperm Chromatin Dispersion Test: A Simple Method for the Determination of Sperm DNA Fragmentation. Journal of Andrology. 2003;24(1):59-66.

61. Menezo Y, Clement P, Amar E. Evaluation of sperm DNA structure, fragmentation and decondensation: an essential tool in the assessment of male infertility. Transl Androl Urol. 2017;6(Suppl 4):S553-S6.

62. Sakkas D, Seli E, Manicardi GC, Nijs M, Ombelet W, Bizzaro D. The presence of abnormal spermatozoa in the ejaculate: did apoptosis fail? Hum Fertil (Camb). 2004;7(2):99-103.

63. Aitken RJ. Impact of oxidative stress on male and female germ cells: implications for fertility. Reproduction. 2020;159(4):R189-R201.

64. Agarwal A, Virk G, Ong C, du Plessis SS. Effect of oxidative stress on male reproduction. World J Mens Health. 2014;32(1):1-17.

65. Aitken RJ, Smith TB, Jobling MS, Baker MA, De luliis GN. Oxidative stress and male reproductive health. Asian J Androl. 2014;16(1):31-8.

66. Vaughan DA, Tirado E, Garcia D, Datta V, Sakkas D. DNA fragmentation of sperm: a radical examination of the contribution of oxidative stress and age in 16945 semen samples. Hum Reprod. 2020;35(10):2188-96.

67. Oleszczuk K, Augustinsson L, Bayat N, Giwercman A, Bungum M. Prevalence of high DNA fragmentation index in male partners of unexplained infertile couples. Andrology. 2013;1(3):357-60.

68. Santi D, Spaggiari G, Simoni M. Sperm DNA fragmentation index as a promising predictive tool for male infertility diagnosis and treatment management - meta-analyses. Reprod Biomed Online. 2018;37(3):315-26.

69. Sakkas D, Alvarez JG. Sperm DNA fragmentation: mechanisms of origin, impact on reproductive outcome, and analysis. Fertil Steril. 2010;93(4):1027-36. 
70. Jin J, Pan C, Fei Q, Ni W, Yang X, Zhang L, et al. Effect of sperm DNA fragmentation on the clinical outcomes for in vitro fertilization and intracytoplasmic sperm injection in women with different ovarian reserves. Fertil Steril. 2015;103(4):910-6.

71. Horta F, Catt S, Ramachandran P, Vollenhoven B, Temple-Smith P. Female ageing affects the DNA repair capacity of oocytes in IVF using a controlled model of sperm DNA damage in mice. Hum Reprod. 2020;35(3):529-44.

72. Zheng WW, Song G, Wang QL, Liu SW, Zhu XL, Deng SM, et al. Sperm DNA damage has a negative effect on early embryonic development following in vitro fertilization. Asian J Androl. 2018;20(1):75-9.

73. Giwercman A, Lindstedt L, Larsson M, Bungum M, Spano M, Levine RJ, et al. Sperm chromatin structure assay as an independent predictor of fertility in vivo: a case-control study. International journal of andrology. 2010;33(1):e221-7.

74. Avendano C, Franchi A, Duran H, Oehninger S. DNA fragmentation of normal spermatozoa negatively impacts embryo quality and intracytoplasmic sperm injection outcome. Fertil Steril. 2010;94(2):549-57.

75. Bounartzi T, Dafopoulos K, Anifandis G, Messini Cl, Koutsonikou C, Kouris S, et al. Pregnancy prediction by free sperm DNA and sperm DNA fragmentation in semen specimens of IVF/ICSI-ET patients. Hum Fertil (Camb). 2016;19(1):56-62.

76. Bungum M, Humaidan P, Axmon A, Spano M, Bungum L, Erenpreiss J, et al. Sperm DNA integrity assessment in prediction of assisted reproduction technology outcome. Hum Reprod. 2007;22(1):174-9.

77. Simon L, Zini A, Dyachenko A, Ciampi A, Carrell DT. A systematic review and meta-analysis to determine the effect of sperm DNA damage on in vitro fertilization and intracytoplasmic sperm injection outcome. Asian J Androl. 2017;19(1):80-90.

78. Eisenberg ML, Sapra KJ, Kim SD, Chen Z, Buck Louis GM. Semen quality and pregnancy loss in a contemporary cohort of couples recruited before conception: data from the Longitudinal Investigation of Fertility and the Environment (LIFE) Study. Fertil Steril. 2017;108(4):613-9.

79. Carlini T, Paoli D, Pelloni M, Faja F, Dal Lago A, Lombardo F, et al. Sperm DNA fragmentation in Italian couples with recurrent pregnancy loss. Reprod Biomed Online. 2017;34(1):58-65.

80. Bareh GM, Jacoby E, Binkley P, Chang TC, Schenken RS, Robinson RD. Sperm deoxyribonucleic acid fragmentation assessment in normozoospermic male partners of couples with unexplained recurrent pregnancy loss: a prospective study. Fertil Steril. 2016;105(2):329-36 e1.

81. Brahem S, Mehdi M, Landolsi H, Mougou S, Elghezal H, Saad A. Semen parameters and sperm DNA fragmentation as causes of recurrent pregnancy loss. Urology. 2011;78(4):792-6.

82. Sanchez-Martin P, Sanchez-Martin F, Gonzalez-Martinez M, Gosalvez J. Increased pregnancy after reduced male abstinence. Syst Biol Reprod Med. 2013;59(5):256-60.

83. Cnattingius S EA, Gunnarskog J, Källén B. A quality study of a medical birth registry. Scand J Soc Med. 1990;18(2):143-8.

84. National Board of Health and Welfare CoE. The Swedish Medical Birth Register; A summary of content and quality (Article no. 2003.112.3) https://www.socialstyrelsen.se/globalassets/sharepointdokument/artikelkatalog/ovrigt/2003-112-3_20031123.pdf 2003

85. National Board of Health and Welfare CoE. Health and Medical Care, Pregnancies, Deliveries and Newborn Infants, The Swedish Medical Birth Register 1973.2014 (Article No 2015-12-27) 
https://www.socialstyrelsen.se/globalassets/sharepointdokument/artikelkatalog/statistik/2015-12-27.pdf 2015

86. National Board of Health and Welfare. Childbirth after IVF treatment in Sweden 1982-2001 https://www.socialstyrelsen.se/globalassets/sharepointdokument/artikelkatalog/statistik/2006-112-1_20061121.pdf

87. National Board of Health and Welfare CoE. Kvalitet och innehåll $i$ patientregistret - Utskrivningar från slutenvård 1964-2006 och besök i öppenvård (exklusive primärvårdsbesök) 1997-2006.

https://www.socialstyrelsen.se/globalassets/sharepointdokument/artikelkatalog/statistik/2009-125-15_200912515_rev2.pdf

88. National Board of Health and Welfare CoE. Kodningskvalitet i patientregistret; Ett nytt verktyg för att mäta kvalitet. https://www.socialstyrelsen.se/globalassets/sharepointdokument/artikelkatalog/statistik/2013-3-10.pdf

89. Ludvigsson JF, Andersson E, Ekbom A, Feychting M, Kim JL, Reuterwall C, et al. External review and validation of the Swedish national inpatient register. BMC Public Health. 2011;11:450.

90. National Board of Health and Welfare CoE. Dödsorsaksstatistik, Historik, produktionsmetoder och tillförlitlighet.

https://www.socialstyrelsen.se/globalassets/sharepointdokument/artikelkatalog/statistik/2010-4-33.pdf

91. National Board of Health and Welfare CoE. The Cause of Death Register 2019 [Available from: https://www.socialstyrelsen.se/statistik-och-data/register/allaregister/dodsorsaksregistret/.

92. Statistics Sweden. Description of the Population in Sweden 2008 http://share.scb.se/ov9993/data/publikationer/statistik/_publikationer/be0101_2 008a01_br_be0109text.pdf2009 [

93. Statistics Sweden. Total Population Register - Description of the Register 2017 [Available from:

https://www.scb.se/contentassets/8f66bcf5abc34d0b98afa4fcbfc0e060/rtb-bar2016-eng.pdf.

94. Statistics Sweden. Multi-Generation register 2016; a description of contents and quality. (Serial no 2017:2)

https://www.scb.se/contentassets/731ea818c63b406a928b9b824ad7f818/ov99 99_2016a01_br_be96br1702.pdf

95. Statistics Sweden. Det statistiska registrets framställning och kvalitet Flergenerationsregistret 20202020 [Available from:

http://www.sverigeisiffror.scb.se/contentassets/8dfda0b71365499c81dc27297b cb5f78/be0102_star_2020.pdf.

96. Evenson DP. Sperm Chromatin Structure Assay (SCSA®). In: Carrell DT, Aston KI, editors. Spermatogenesis: Methods and Protocols. Totowa, NJ: Humana Press; 2013. p. 147-64.

97. Evenson DP, Larson KL, Jost LK. Sperm Chromatin Structure Assay: Its Clinical Use for Detecting Sperm DNA Fragmentation in Male Infertility and Comparisons With Other Techniques. Journal of Andrology. 2002;23(1):25-43.

98. Giavarina D. Understanding Bland Altman analysis. Biochem Med (Zagreb). 2015;25(2):141-51.

99. Association WM. World Medical Association Declaration of Helsinki Ethical Principles for Medical Research. JAMA. 2013;310(20):2191-4.

100. Statistics Sweden. Smoking habits, daily smokers, men 30-39 years 2008-2011 2020 [Available from:

http://www.statistikdatabasen.scb.se/pxweb/sv/ssd/START_LE_LE0101_LE 0101H/LE01012019H06/table/tableViewLayout1/. 
101. Statistics Sweden. Tobacco habits. Daily use of snuff, men 30-39 years 200820112020 [Available from:

http://www.statistikdatabasen.scb.se/pxweb/sv/ssd/START_LE_LE0101__LE 0101H/LE01012019H06/table/tableViewLayout1/.

102. Liffner S, Nedstrand E, Bladh M, Rodriguez-Martinez H, Hammar M, Sydsjo G. Birth characteristics in men with infertility. Reprod Biomed Online. 2020;41(3):455-63.

103. Statistics Sweden. Mean age at birth of third child or more, fathers, 2000-2012 2020 [Available from:

http://www.statistikdatabasen.scb.se/pxweb/sv/ssd/START_BE_BE0101_B E0101H/MedelAlder1/table/tableViewLayout1/.

104. Dupont C, Faure C, Daoud F, Gautier B, Czernichow S, Levy R, et al. Metabolic syndrome and smoking are independent risk factors of male idiopathic infertility. Basic Clin Androl. 2019;29:9.

105. Kasturi SS, Tannir J, Brannigan RE. The metabolic syndrome and male infertility. J Androl. 2008;29(3):251-9.

106. Schisterman EF, Mumford SL, Browne RW, Barr DB, Chen Z, Louis GM. Lipid concentrations and couple fecundity: the LIFE study. J Clin Endocrinol Metab. 2014;99(8):2786-94.

107. Barratt CLR, Bjorndahl L, De Jonge CJ, Lamb DJ, Osorio Martini F, McLachlan $\mathrm{R}$, et al. The diagnosis of male infertility: an analysis of the evidence to support the development of global WHO guidance-challenges and future research opportunities. Hum Reprod Update. 2017;23(6):660-80.

108. Parn T, Grau Ruiz R, Kunovac Kallak T, Ruiz JR, Davey E, Hreinsson J, et al. Physical activity, fatness, educational level and snuff consumption as determinants of semen quality: findings of the ActiART study. Reprod Biomed Online. 2015;31(1):108-19.

109. National Board of Health and Welfare. Statistik om graviditeter, förlossningar och nyfödda barn 20192020 [Available from:

https://www.socialstyrelsen.se/globalassets/sharepoint-

dokument/artikelkatalog/statistik/2020-12-7051.pdf.

110. Skarin Nordenvall A, Chen Q, Norrby C, Lundholm C, Frisen L, Nordenstrom A, et al. Fertility in adult men born with hypospadias: A nationwide register-based cohort study on birthrates, the use of assisted reproductive technologies and infertility. Andrology. 2020;8(2):372-80.

111. Kim GY. What should be done for men with sperm DNA fragmentation? Clin Exp Reprod Med. 2018;45(3):101-9.

112. Virro MR, Larson-Cook KL, Evenson DP. Sperm chromatin structure assay (SCSA) parameters are related to fertilization, blastocyst development, and ongoing pregnancy in in vitro fertilization and intracytoplasmic sperm injection cycles. Fertil Steril. 2004;81(5):1289-95.

113. Jerre E, Bungum M, Evenson DP, Giwercman A. Sperm chromatin structure assay high DNA stainability sperm as a marker of early miscarriage after intracytoplasmic sperm injection. Fertil Steril. 2019;112(1):46-53.

114. Muratori M, Tarozzi N, Cambi M, Boni L, lorio AL, Passaro C, et al. Variation of DNA Fragmentation Levels During Density Gradient Sperm Selection for Assisted Reproduction Techniques: A Possible New Male Predictive Parameter of Pregnancy? Medicine (Baltimore). 2016;95(20):e3624.

115. De Gheselle S, Deroose A, Stevens J, Hiel M, Tilleman K. A methodological validation of an easy one-step swimout semen preparation procedure for 
selecting DNA fragmentation-free spermatozoa for ICSI. Andrologia. 2020;52(11):e13852.

116. Evenson DP, Djira G, Kasperson K, Christianson J. Relationships between the age of 25,445 men attending infertility clinics and sperm chromatin structure assay (SCSA) defined sperm DNA and chromatin integrity. Fertil Steril. 2020;114(2):311-20.

117. Albani E, Castellano S, Gurrieri B, Arruzzolo L, Negri L, Borroni EM, et al. Male age: negative impact on sperm DNA fragmentation. Aging. 2019;11(9):2749-61.

118. Thygesen LC, Ersboll AK. When the entire population is the sample: strengths and limitations in register-based epidemiology. Eur j Epidemiol. 2014;29:5515558.

119. Mattsson K, Kallen K, Rignell-Hydbom A, Lindh CH, Jonsson BA, Gustafsson $\mathrm{P}$, et al. Cotinine Validation of Self-Reported Smoking During Pregnancy in the Swedish Medical Birth Register. Nicotine Tob Res. 2016;18(1):79-83.

120. Sharkey DJ, Tremellen KP, Jasper MJ, Gemzell-Danielsson K, Robertson SA. Seminal fluid induces leukocyte recruitment and cytokine and chemokine mRNA expression in the human cervix after coitus. J Immunol. 2012;188(5):2445-54.

121. Robertson SA, Sharkey DJ. Seminal fluid and fertility in women. Fertil Steril. 2016;106(3):511-9. 


\section{Papers}

The papers associated with this thesis have been removed for copyright reasons. For more details about these see:

https://doi.org/10.3384/9789179290504 


\section{FACULTY OF MEDICINE AND HEALTH SCIENCES}

Linköping University Medical Dissertation No. 1793, 2021

Department of Biomedical and Clinical Sciences

Linköping University

SE-581 83 Linköping, Sweden

www.liu.se 